NBER WORKING PAPER SERIES

\title{
LABOR DROPS: EXPERIMENTAL EVIDENCE ON THE RETURN TO ADDITIONAL LABOR IN MICROENTERPRISES
}

\author{
Suresh De Mel \\ David McKenzie \\ Christopher Woodruff \\ Working Paper 23005 \\ http://www.nber.org/papers/w23005 \\ NATIONAL BUREAU OF ECONOMIC RESEARCH \\ 1050 Massachusetts Avenue \\ Cambridge, MA 02138 \\ December 2016
}

Funding for this project was provided by the National Science Foundation (SES0820375), the World Bank, DfID, the Knowledge for Change Trust Fund, the Diagnostic Facility for Shared Growth Trust Fund, the Strategic Research Program Trust Fund, and the Templeton Foundation. Matthew Groh provided excellent research assistance. The surveys and interventions were carried out with aplomb by the Kandy Consulting Group, without whose assistance we would not have been able to undertake the project. The surveys and interventions in this project were carried out under approval from the Human Research Protection Program at UCSD, Project \#080861S. The views expressed herein are those of the authors and do not necessarily reflect the views of the National Bureau of Economic Research.

NBER working papers are circulated for discussion and comment purposes. They have not been peer-reviewed or been subject to the review by the NBER Board of Directors that accompanies official NBER publications.

(C) 2016 by Suresh De Mel, David McKenzie, and Christopher Woodruff. All rights reserved. Short sections of text, not to exceed two paragraphs, may be quoted without explicit permission provided that full credit, including $\odot$ notice, is given to the source. 
Labor Drops: Experimental Evidence on the Return to Additional Labor in Microenterprises Suresh De Mel, David McKenzie, and Christopher Woodruff

NBER Working Paper No. 23005

December 2016

JEL No. C93,D22,L26,O12,O17

\section{ABSTRACT}

The majority of enterprises in developing countries have no paid workers. Is this optimal, or the result of frictions in labor markets? We conduct an experiment providing wage subsidies to randomly chosen microenterprises in Sri Lanka. In the presence of frictions, a short-term subsidy could have a lasting impact on employment. We find the subsidy induced firms to hire, but there was no lasting impact on employment, profitability, or sales. Analysis rules out several theoretical mechanisms that could result in sub-optimally low employment. We conclude that labor market frictions are not the reason own-account workers do not become employers.

Suresh De Mel

University of Peradeniya

demel.suresh@gmail.com

David McKenzie

The World Bank, MSN MC3-307

1818 H Street N.W.

Washington, DC 20433

dmckenzie@worldbank.org
Christopher Woodruff

Queen Elizabeth House

University of Oxford

OX1 3TB

$\mathrm{UK}$

and NBER

christopher.woodruff@qeh.ox.ac.uk

An online appendix is available at http://www.nber.org/data-appendix/w23005 


\section{Introduction}

The modal firm in most developing countries consists of a self-employed entrepreneur with no paid employees. Do labor market frictions prevent more of these firm-owners from hiring workers? The development literature has long characterized rural labor markets as incomplete, leading to non-separation of household production and consumption decisions (Rosenzweig, 1988 provides a review). But there is theoretical debate as to the extent to which there are frictions in urban markets. A long-held view has been that of dualism, in which large, formal firms face serious frictions from minimum wages and other regulations, but smaller firms operate without frictions in an unregulated sector (e.g. Fields 1975; Rauch 1991; Zenou 2008).

However, more recent literature argues that minimum wages and other regulations can have spillovers that distort the informal sector (Freeman, 2010). Moreover, even in the absence of regulatory distortions, there can be other important frictions. For example, training costs coupled with high worker turnover may imply that new workers should pay to work at firms for some initial period, something limited contracting options (Stiglitz, 1974) usually rule out. ${ }^{1}$ Other frictions arise from imperfect information. The diversity of technologies and products in urban markets may make it harder to identify the right match for a job (Rosenzweig, 1988); supervision and search costs may make it prohibitive for firms to expand labor beyond family members (Emran et al, 2008); and owners may lack information even about their own entrepreneurial ability (Jovanovic, 1982).

We conduct an experiment to test directly whether hiring additional labor can benefit small firms in Sri Lanka. Previous work providing "capital drops" to microenterprises in Sri Lanka found evidence of capital constraints, but also found that capital alone was not enough to transition firms to hiring workers (de Mel et al, 2008, 2012). In this paper, we report on an attempt to drop labor into firms by offering microenterprises temporary wage subsidies equivalent to roughly half the wage of an unskilled worker for a period of six months. In the absence of frictions, a short-term subsidy should increase employment during the subsidy period, but have no lasting impact, whereas under the alternative labor market models, a temporary subsidy can have longterm impacts on firm size.

\footnotetext{
${ }^{1}$ Apprenticeships common in certain labor markets appear to reflect the low initial marginal product of labor. But as Hardy and McCasland (2015) show, the efficiency of the apprenticeship solution is compromised by credit constraints and information frictions.
} 
We find that 24 percent of firms take the subsidy to hire a worker, resulting in an increase in employment in the treated firms during the subsidy period. However, using 12 rounds of survey data to track the dynamics of adjustment for four years post-subsidy, we show there is no lasting effect on employment, firm profitability, or sales. A combination of shedding of workers by treated firms and additional hiring by control firms completely eliminates the employment gap within two years. The only long-term effect is that the subsidy appears to have increased survival rates for firms that initially had low-capital and low profitability.

We use the data generated by the experiment to differentiate between competing views of urban labor markets for small firms. A combination of detailed survey data and an analysis of heterogeneous treatment effects yields no evidence that owners are learning more about their ability to manage workers, and suggests that search is not excessively costly for such firms. Complementary treatments providing either capital or training show that the lack of long-term effect does not appear to be due to lack of complementary capital or skills. Instead, the estimated return to additional labor during the subsidy period appears similar in magnitude to the subsidy offered, suggesting additional workers bring no more value to the firm than their unsubsidized labor cost. As such, our results imply that labor markets appear to be functioning reasonably well for microenterprises, and do not appear to be the constraint to their growth that some theories might suggest.

This paper contributes to a recent experimental literature on frictions in urban labor markets in developing countries. Much of this literature focuses on interventions to help particular jobseekers find jobs, by directly offering the job seekers wage subsidies (Galasso et al., 2004, Groh et al. 2016, Levinsohn et al., 2014); and/or by trying to improve the search and matching process through transport subsidies and skill certification (Groh et al, 2015; Abel et al, 2016; Abede et al, 2016). Some, but not all, of these studies have found modest improvements in formal employment as a result of this assistance, consistent with constraints to workers finding jobs in larger, more formal firms. These studies have not explicitly focused on helping workers find employment in microenterprises, and have not typically found significant effects on informal employment.

The literature examining labor market frictions from the firm side is much less developed, with several recent studies beginning after this paper. Cohen (2016) develops a structural model using 
data from our earlier capital experiment in Sri Lanka and finds, under specific assumptions, that microenterprises do seem to be constrained in expanding labor as their capital grows. Bertrand and Crépon (2016) find that firms with between five and 300 employees in South Africa hire more workers when offered labor law advice that explains to them that firing restrictions are not as burdensome as many firms think, suggesting constraints on labor expansion for SMEs. In work most closely related to ours, Hardy and McCasland (2015) randomly place apprentices with small firms in Ghana, and find firms retain this extra labor for at least six months, and earn higher profits in doing so. Their context, in which employees typically pay for entry-level positions in order to get trained, differs from the standard labor market contractual form in most developing countries (including Sri Lanka). If their results persist over time, this may explain the difference in results.

The remainder of the paper is structured as follows: Section 2 outlines different theories of why small firms might be labor constrained, and the implications for the impact of a wage subsidy; Section 3 details the experimental design and intervention; Section 4 discusses take-up; Section 5 provides the results; Section 6 investigates different mechanisms leading to these results; and Section 7 concludes.

\section{Theory: Why Might Small Firms Be Labor-Constrained, and How Could a Temporary Subsidy Have Lasting Impacts on Firm Employment?}

The most common firm size in many developing countries, including Sri Lanka, is one - an owner with no paid employees. What explains the small size of these firms, and how might we expect a temporary wage subsidy to change this firm size?

\subsection{Classic complete markets model}

Consider first the standard complete markets model of firm size of Lucas (1978), where differences in employment size among firms facing the same output production technology $f($. reflect differences in their management ability and productivity, $\theta$. A firm facing a wage rate for workers $w$, and an interest rate on capital $r$, will choose capital, $K$ and labor, $L$ to maximize profits $\mathrm{f}(\theta, \mathrm{K}, \mathrm{L})-w \mathrm{~L}-r \mathrm{~K}$. Firms are small and are assumed to be price-takers, who can sell all output they produce at a price normalized to 1 . This yields the familiar first-order conditions in 
which the optimal levels of capital $\left(\mathrm{K}^{*}\right)$ and of labor $\left(\mathrm{L}^{*}\right)$ are chosen such that marginal products of labor and capital are equal to the wage rate and interest rate respectively ${ }^{2}$ :

$$
\begin{aligned}
& f_{L}\left(\theta, K^{*}, L^{*}\right)=w \\
& f_{K}\left(\theta, K^{*}, L^{*}\right)=r
\end{aligned}
$$

If managerial ability is a complement, rather than a substitute for capital and labor, then in this model firms with zero workers are those with low managerial ability.

Consider a temporary wage subsidy in this model. This lowers the effective wage rate for additional workers from $w$ to $w^{\prime}$. Resolving the first-order conditions (1) and (2) at this lower wage will result in firms choosing a higher levels of employment $L^{\prime}$, and producing more output, and therefore more sales and higher profits in the short-run. However, once the subsidy ends, $w$ returns to its previous level, and - so long as $\theta$ is unchanged by the intervention - output, profits, and employment return to their pre-subsidy levels.

\subsection{Standard model with credit constraints}

Now consider credit market constraints which limit the ability of firm owners to borrow to finance capital investments. Let $A$ be the wealth of the business owner. This wealth can be leveraged in financial markets by some amount (b-1), with $b \geq 1$ being a measure of borrowing constraints. The capital constraint is then $\mathrm{K} \leq \mathrm{b} A$. Then the new equilibrium levels of capital, $\mathrm{K}^{* *}$, and $\mathrm{L}^{* *}$ solve:

$$
\begin{aligned}
f_{L}\left(\theta, K^{* *}, L^{* *}\right) & =w \\
f_{K}\left(\theta, K^{* *}, L^{* *}\right) & =r+\lambda b
\end{aligned}
$$

Where $\lambda$ is the Lagrange-multiplier on the borrowing constraint. In this set-up, equilibrium output and equilibrium capital are lower than in the no constraint case $\left(\mathrm{K}^{* *}<\mathrm{K}^{*}\right)$, but $\mathrm{L}^{* *}$ may be greater than or lower than $\mathrm{L}^{*}$ depending on the shape of the production function: firms may substitute capital for labor and end up with more employment than in unconstrained states, or they may find labor less productive without complementary capital and so hire less labor than in unconstrained states.

\footnotetext{
${ }^{2}$ For simplicity of exposition we assume the owner's own labor supply is inelastic here, but in our empirical work will also examine the labor supply response of the owner to our interventions.
} 
The wage subsidy treatment should then have a similar impact as in the standard model without constraints, except that the presence of credit constraints may limit the ability of the firm owner to adjust capital upwards to provide the capital needed for additional labor to work with. This would act to reduce the responsiveness of firms to a wage subsidy in the short-run. There should again be no long-run impact. ${ }^{3}$ An exception to this prediction of no long-run impact may occur if firms face a lower-bound of profitability below which they shut down if they can't borrow. The short-term wage subsidy, by temporarily providing a period of higher profits, may allow the firm to survive shocks that would otherwise cause them to close down, and thereby remain in business (de Mel et al, 2012).

\subsection{Labor market constraints}

The motivation for a wage subsidy instead lies in the idea that there are firms for whom it would be beneficial to hire more workers, but have not done so due to various constraints on hiring. There are several possible reasons the labor market may not clear, and why a short-term subsidy may therefore have a lasting impact.

The first set of frictions are those involved in identifying, hiring, and firing workers in an environment where firm owners are unsure of worker types. For example, the search and matching theory of Mortensen and Pissarides (1994) features firms with vacancies who find it difficult to match with qualified workers. If small firm owners find it hard to identify good workers they can trust, or find it socially or financially costly to fire them if they are bad, then this cost of hiring will deter some firm owners from hiring workers who, if they turn out to be good matches, will increase firm profits. A wage subsidy can subsidize these hiring costs and lead firms to take chances on new workers. This will increase employment in the short run, and since firms will retain workers who are good matches, also have a long-term impact on employment.

A related possibility is that firm owners may not know their own type $(\theta)$, as in Jovanovic (1982). Let $\theta^{*}$ be the managerial ability cutoff at which the unconstrained optimum is to hire a worker. Let $\tilde{\theta}$ be the belief a firm owner has about their own ability. If we consider a distribution

\footnotetext{
${ }^{3}$ If the firm is credit constrained and the wage subsidy increases profits in the short run, these profits may be reinvested, with a resulting long-term effect. But the upper bound on the additional profits in this case is the amount of the subsidy. In our case, that is 28,000 LKR, while the median (mean) capital stock excluding land and buildings among the firms in our sample is $160,000(345,000)$ LKR.
} 
of initial beliefs about own managerial ability, then all owners with initial beliefs $\tilde{\theta} \geq \theta^{*}$ will have tried hiring a worker before, and either found the worker to be productive and kept the worker, or not to have been productive and not have kept the worker. The pool of firm owners who have not previously hired a worker will then consist of owners with low actual managerial ability, as well as those with high actual managerial ability who believe they have low ability. The wage subsidy induces some of these owners to take on a worker while the subsidy is in effect. If this enables them to learn their ability type, then some of these firm owners will discover they were incorrect in their beliefs and retain the worker after the subsidy ends.

A third set of labor market constraints may arise from the combination of job-specific human capital and either formal or informal minimum wages that prevent untrained workers being paid their low marginal product (or even being charged to learn on-the-job as in the apprenticeship system studied in Hardy and McCasland, 2015). Workers may be less productive in their first few months while they learn the specifics of the job, with productivity increasing over time through on-the-job training. For example, one of the firms in our study was a wedding videographer, and said it took two months of training before a new worker could be sent out to film a small wedding by himself. In the standard model above, the firm would pay a new worker his or her marginal product, so would pay a low (perhaps even zero or negative) wage at the beginning, and then a higher wage once productivity increases. However, poverty constraints, minimum wage laws, and social norms may limit the ability of workers to take low initial wages to compensate for their low initial productivity. This imposes the constraint $w \geq m$ on the optimization problem, where $m$ is this lower bound on the wages that can be paid. A short-term subsidy can compensate firms for the low productivity of workers during this training period, and for the fixed costs of hiring workers. If the productivity of workers increases during the period wages are subsidized (Bell et al, 1999), then they may be sufficiently productive after the subsidies end that firms are willing to pay them wage $w \geq m$ and keep them employed. ${ }^{4}$

A fourth possibility is that of non-convexities in hiring labor: firms may be only able to hire a worker full-time, or not at all. As a result, some of the firm owners with 0 workers may have optimal firm sizes of say 0.4 workers. Given the integer constraint, these firms may be more

\footnotetext{
${ }^{4}$ Given enough friction in labor markets, firms may be able to recapture initial losses by paying wages below the marginal product of labor after workers become more productive. But movement of workers across firms may prevent this.
} 
profitable without a worker than with a worker. The subsidy may change this optimal in the short-term to be closer to one worker, leading to hiring. The model would predict that, all else equal, firm owners with higher management ability will be closer to the threshold, and so be more likely to respond to the intervention. However, since the wage subsidy doesn't change this non-convexity, employment afterwards should return back to the original level.

The first three sources of labor market frictions offer the possibility that some firms are small because of these frictions, and that a short-term subsidy may have lasting impacts on firm size. However, if labor markets function reasonably well, then we would predict a subsidy to have no lasting impact on employment. The above theories also offer predictions for which types of firms may respond more, at least in the short-run, to a subsidy - those with higher management ability if non-convexities are an issue, younger firms and those with no previous experience with workers if learning one's type is an issue, and wealthier firms if credit constraints bind and capital is needed to make new workers productive.

\section{Experimental Design and Data Collection}

\subsection{The Sample}

We aimed to select a random sample of urban microenterprises with two or fewer paid employees, owned by males aged 20 to 45 and operating in non-agricultural sectors. We chose to focus on male-owned enterprises because our previous work with capital grants showed that male-owned businesses appeared to have more growth potential, with female-owned firms facing additional constraints (de Mel et al. 2008, 2009). We took a random sample of firms, rather than screening on interest in hiring workers, in order to understand whether the average microenterprise is labor-constrained.

To attain this sample of firms, we selected Grama Niladhara (GN) divisions within Colombo, Kandy, and the Galle-Matara areas, and went door-to-door listing households from a random starting point. The listing collected information on each adult active in the labor force, and was used to screen on age, self-employment status, and sector to select firms for our sample. This was then followed by a baseline survey which collected details of the business and the owner. The first phase of this occurred in April 2008 (see Appendix 1 for a timeline) as part of a larger panel survey that also included other urban areas in Sri Lanka. We then returned in October 2008 and conducted a booster listing exercise and survey in neighboring GNs in order to attain a larger 
sample for our intervention, re-interviewing those interviewed in the original sample. After dropping those firms that had closed since the first baseline, this gave a sample of 1533 firms. Appendix 2 provides more details on the sampling methodology.

\subsection{The Intervention}

Our main intervention consists of a temporary wage subsidy to firms with the purpose of encouraging owners to hire an additional full-time employee. The April 2009 survey - taken before anyone was made aware of the wage incentive program - asked for information about each employee currently working at the enterprise. In early July, we notified those assigned to the wage incentive treatment that we would pay a flat amount of 4000 LKR per month for a period of six months if they hired an additional employee working at least 30 hours per week, and a flat amount of 2000 LKR per month for a further two months. The employee had to be someone living outside the owner's household and could not be an immediate family member (spouse, parents, siblings, and children). Participants were told that payments would start in August 2009 and, regardless of when the worker was hired, end by May 2010. In other words, workers had to be hired by 1 October, 2009 for the full amount of the subsidy to be paid. The subsidy represents about half of the earnings of a typical unskilled worker. It is also approximately half the minimum wage, which in Sri Lanka is set by Wage Boards and ranged from approximately 7,000 to 8,000 LKR per month during the time of the intervention. Note that the minimum wages only apply to formally registered workers.

Several studies of the impacts of wage subsidies on workers in developing countries have found employers reluctant to register hired workers formally in the social security system where they would have to pay labor taxes (e.g. Galasso et al, 2004; Groh et al, 2016). Since the vast majority of microenterprises in Sri Lanka do not register their workers (de Mel et al, 2013), we did not make legal registration of workers a requirement of the program. Once we were notified by the participant that a worker had been hired, we sent a research assistant to conduct an interview with the new employee. We also conducted a short interview with the owner focused on the search and hiring process. Research assistants then made occasional unannounced visits to the enterprise to make sure the employee was working. In a few cases, the research assistants were unable to confirm that the employee was in fact working full time. In all such cases, within a few visits the owner notified us that the employee was no longer working, and we removed the 
subsidy. We believe this process and these spot checks were sufficient to root out minimize 'phantom' employees.

In order to determine whether the effectiveness of the wage subsidy differs with the availability of complementary inputs, we also carried out two supplementary interventions. The first was a savings intervention, in which individuals were offered a savings account in which we matched deposits made up to a specified amount. This took place before the wage subsidies started, and the goal of this intervention was to enable firm owners to build up a balance of savings, which they could then use to supplement the worker with any additional capital required to make this worker more productive. The second was a business training intervention, which also took place before the wage subsidies started. Firm owners were offered the ILO's Improve Your Business (IYB) training, to allow for the possibility that better business practices are needed in order to be able to successfully employ additional labor. Appendix 3 describes these supplementary interventions in more detail.

\subsection{Randomization and Balance}

After the baseline survey was conducted with those in the booster sample, we stratified firms into six strata using geographic region (Colombo, Kandy, or Galle/Matara) and sector (retail or manufacturing and services). Within each stratum we then randomly assigned $18.7 \%$ to the control group (286/1533), 16.3\% (250/1533) to get the wage subsidy program alone, $19.3 \%$ $(297 / 1533)$ to get the wage subsidy and the supplementary savings program, 19.3\% $(297 / 1533)$ to get the wage subsidy and the supplementary training program, $7.3 \%(112 / 1533)$ to get the supplementary savings program alone, 9.2\% (141/1533) to get the supplementary training program alone, and $9.8 \%$ (150) to get the supplementary training and savings programs.

Given the number of groups and the irregular sample sizes across groups, it was not possible to stratify further within strata in doing the randomization. ${ }^{5}$ In order to improve balance further on a set of key variables likely to be related to business outcomes we therefore employed a rerandomization procedure. We re-randomized 1000 times and in each randomization conducted an F-test for equality of means across the seven treatment groups for a set of 13 baseline variables listed in Table 1, including profits, ability, management practices, number of

\footnotetext{
${ }^{5}$ We choose to put more observations in treatment groups where we were concerned that take-up would be more of an issue, in order to have sufficient observations in each cell with which to examine intervention take-up.
} 
employees, and business assets. One potential pitfall for this approach can arise from outliers, so we also included dummy variables for profits and assets in the top or bottom 5 percent to reduce the possibility that balance on means was disguising large outliers. We then took the maximum F-statistic across these 13 variables, and then choose the random assignment from among the 1000 allocations that had the minimum maximum F-statistic. In all reported regressions, we control for the baseline measures of these variables and for the full set of strata dummies, which Bruhn and McKenzie (2009) show gives the correct size and power after re-randomizing.

For the majority of this paper we use the sample of 286 pure control enterprises and 250 enterprises assigned to the wage subsidy treatment alone. Table 1 shows that we achieved balance at baseline on a set of important observable variables: we are unable to reject the null hypothesis that these observables are jointly orthogonal to treatment status $(p=0.734)$. In addition, we follow Imbens and Rubin (2015) in considering the normalized difference $\left(\bar{X}_{T}-\bar{X}_{C}\right) / \sqrt{\left(\bar{S}_{T}{ }^{2}+\bar{S}_{C}{ }^{2}\right) / 2}$ as a measure of balance, where $\bar{X}_{j}$ and $\bar{s}_{j}{ }^{2}$ are the sample mean and variance of the variable for the treatment group $(j=T)$ and control group $(j=C)$ respectively. These normalized differences provide a scale-invariant measure of the difference in locations, and show good balance, with the largest differences less than 0.2 standard deviations. Appendix 3 also shows balance for the supplementary interventions.

Table 1 helps provide a descriptive picture of the owners of these firms and their businesses. The average owner is 35 years old, has finished 10 years of schooling, and works 58 hours a week in their business. Most firms do not have any paid employees, with only 11 percent having at least one paid worker, and an average of 0.17 paid workers per firm. The businesses are mostly informal (only one-third are registered for tax purposes), with 40 percent in retail (e.g. groceries, hardware, plastic products), and the remainder in manufacturing (e.g. tailoring, brasswork, carpentry, food production) and services (e.g. electricians, vehicle repair, haircutting, transportation). In 2008, mean monthly profits were 14,184 LKR (approx.. US\$130) on 46,434 LKR (approx.. US\$430) of monthly sales. ${ }^{6}$

\subsection{Follow-up Surveys and Attrition}

\footnotetext{
${ }^{6}$ The exchange rate averaged 108 LKR per USD in 2008, was in the 110-115 range from 2009 to 2011, and then averaged 128 LKR per USD in 2012, 129 in 2013, and 130 in 2014.
} 
After the two rounds of baseline, we conducted six-monthly surveys every April and October from 2009 through 2012, followed by additional surveys in April 2013 and April 2014. Altogether this provides 12 rounds of data, including 2 to 3 rounds pre-intervention, 2 rounds during the intervention, and then 7 rounds post-intervention covering four years after the subsidy ended. Each survey round collected operating data for the previous month, along with details of worker hiring and other information. Appendix 4 describes in more detail how key variables were measured. For firms which closed down, we collected information on the current activities of the owner, while for those who could not be interviewed we attempted to obtain basic information on whether the business still existed and the number of employees through observation and discussions with neighbors and family members.

The multiple rounds of follow-up surveys offer several advantages over standard firm studies which rely on a single follow-up. First, they enable us to trace out the trajectory of impacts, to determine whether the treatment effects vary over time. Second, by pooling together data from multiple waves, we can average out seasonality and increase power (McKenzie, 2012). Third, they give us multiple chances to interview firm owners, since owners who may not be available one round may be able to be interviewed in a subsequent round. In order to benefit from all three advantages, we pool together rounds 4 and 5 to capture average effects during the intervention, rounds 6 and 7 to capture average effects in the first year after the subsidy ended, rounds 8 and 9 to capture average effects in the second year after the subsidy ended, and rounds 10, 11, and 12 to capture average effects in years 3 and 4 after the subsidy.

Survey attrition was low for a panel of this length with microenterprises. Round by round attrition rates averaged 5.6 percent for whether the business was in operation, and 9 percent for whether it had a paid worker (see Appendix 5). Table 2 provides summary information on data availability by time period and treatment status after we pool together several data rounds as described above. Data are available for 95 percent of the firms during the intervention period, 95-97 percent in the first year after the subsidy, 92-99 percent in the second year after the subsidy, and 96-98 percent in years 3 to 4 post-subsidy. There is no significant difference in attrition rates by treatment status, except for the second year post-treatment where we have slightly higher data availability for the control group. The last four columns of Table 1 also show that the sample responding to the last survey round remains balanced in terms of observable 
baseline differences. Given the lack of significant differences in attrition by treatment status, and that attrition does not appear to differentially select firms on observables, we maintain a missingat-random assumption in our analysis for those attriting.

An important point of context is that the period of our study coincided with a period of rapid general economic growth in Sri Lanka. When we began our study in 2008, per-capita GNI (in constant 2011 PPP international dollars) was 7,598. ${ }^{7}$ In May 2009, just before our wage subsidy intervention period began, the 25 -year civil war ended, and the Sri Lankan economy grew at 8 to 9 percent per year over the 2010 to 2012 period, with per-capita GNI reaching 10,396 in 2014, the year of our last survey. We are therefore testing the return to additional labor in a growing economy, where firms may be expected to have opportunities to potentially grow.

\section{Take-up and Who Did They Hire?}

\subsection{Take-up}

During the eight months the incentive program was active, 60 of the 250 firms offered only the wage subsidy took it up ( 24 percent). The take-up rates were not statistically different $(p=0.622)$ in the wage subsidy plus savings $(24.2 \%)$, and for the wage subsidy plus training $(21.2 \%)$ treatment groups, giving a total of 196 firms that used the subsidy for at least one month. Conditional on using the subsidy, the median firm used it for seven out of the eight possible months and received a total of 24,000 Rs. in subsidy. Only 17 percent of those using the subsidy used it for 4 or fewer months, and 68 percent used it for 6 months or more.

Table 3 examines the correlates of the take-up decision, building on early analysis presented in de Mel et al. (2010) which only had take-up data through to November 2009. We conduct probits of the probability of using the wage subsidy voucher for the wage subsidy only treatment group, and for all treatment groups offered the wage subsidy. The first column examines firm characteristics, the second owner characteristics, and the third both together. We see that take-up rates are lower in Colombo than in the southern cities of Galle and Matara, with Kandy in between. One possible reason is that wage rates are higher in Colombo, so the flat-rate wage subsidy may cover a lower proportion of the worker's wage there. We find that firm characteristics have very little predictive power for which firms take-up the intervention: there are no significant differences in take-up for those that already had paid workers, for those firms

\footnotetext{
${ }^{7}$ Source: World Development Indicators, World Bank.
} 
that were formally registered, for firms that had more assets at baseline, or by firm age. Instead the skills of the owner appear to matter more. More highly educated owners, and those employing better business practices at baseline are more likely to use the subsidy.

\subsection{Who did they hire?}

In October 2009, we surveyed both the workers hired under the subsidy program and the employers who hired them. These surveys provide data on the characteristics of the workers and the methods the owners used to find them. The hired workers are 31.5 years of age and have 9.8 years of schooling on average. Close relatives of the owners and those living in the owner's household were not eligible to be hired, but 31.3 percent of hired workers are related to the owner in some way; 15.6 percent are female. Most (83.4 percent) were known to the owner before the hiring, and almost half (48.4 percent) say they live within 1 kilometer of the business. Workers report being paid 1,860 LKR per week, with just under one-third of them being paid the subsidy amount or less. ${ }^{8}$ The excess hiring of relatives is concentrated among lower-profit firms, with 41 percent of hires by firms with lower than median baseline profits being related, compared with only 20 percent of hires by firms with above median baseline profits $(p=0.08)$. These low profit firms are also the ones paying the lowest wages: 60 percent of their hires are paid the subsidy amount or less, compared with only 4 percent of the hires by higher-profit firms $(\mathrm{p}<.01)$.

To provide context, we can compare these characteristics with two other groups of hired workers. The first is workers who were working for control firms in April 2010, and who were hired between 2009 and 2010. ${ }^{9}$ We have more limited data on these employees, but we find that they are slightly older (33.6 years of age) and less likely to be female (9.4 percent). They are much less likely to be related to the owner (9.4 percent) and are paid a higher wage (3,217 LKR per week). A second comparison come from surveys conducted in April 2013 and 2014. From

\footnotetext{
${ }^{8}$ There is no significant difference in reported hours worked between those paid 1000 LKR (51.6 hours) per week or less and those paid more than this amount (52.8).

${ }^{9}$ This period encompasses the subsidy period, but is longer so that we have a somewhat larger sample. Among employees at control firms, 32 were hired in 2009 and 21 in 2010. Note that since this sample is workers employed in 2010, it does not include workers hired but no longer working for the enterprise. We note also that this survey provides more limited information about the employees, and that wages are reported by employers (rather than employees and in categories of daily wages, 0-199, 200-399, etc. We estimate average wages from these responses by using the midpoint of the categorical response, which may over- or under-state the level relative to the continuous response given in the survey of hired workers.
} 
these surveys, we use data on workers hired by the firms eligible for the subsidies in the three years following the subsidy period. Compared with the workers hired under the subsidy program, the workers hired later by the same pool of firms are slightly older (32.6 years) and less likely to be female (10.0 percent), though neither of these differences is statistically significant. They are much less likely to be related to the owner (10.0 percent), a difference which is significant at the 1 percent level. They are also slightly less likely to have known the owner previously (71.4 percent) and to live within one kilometer of the business (35.7 percent), though these differences are not statistically significant at conventional levels. They are paid much more (3,350 LKR per week, deflated to fall 2009 prices). On the whole, the characteristics of workers hired postsubsidy are quite similar to those hired in 2009-10 by the control firms. Hence, it appears that workers hired under the subsidy are similar except that they are more likely to be related to the owner, and they are paid a lower wage.

We also asked owners which of 10 methods they used to locate the employee hired through the subsidy program. Employers relied mostly on networks, with asking friends (50 percent), neighbors (33 percent), immediate family ( 21 percent) and extended family (18 percent) for referrals the most common responses. Advertising the position was very rare, used by only 1 percent of the employers, while contacting former employees (7.7 percent), and contacting friends (9.3 percent) and relatives (6.7 percent) directly about the job were used with intermediate frequency. On average, employers used two of the methods. For comparison, in the April 2013 survey, we asked those eligible for the subsidy program how they found employees hired in the two years after the subsidy period. We find similar patterns though the search intensity is somewhat higher, with employers using just over 2 methods. With the post-subsidy hires, employers were more likely to say they advertised (9.6 percent) and contacted former employees (17.2 percent), but referrals through networks of family, neighbors and friends remain the most common search methods by very large margins.

\section{Results}

We first examine whether the wage subsidy changed the survival rates of firms, since, to the extent it did, we need to control for this in examining impacts on employment, profitability and sales. As noted above, our estimation aims to combine the advantages of combining multiple follow-up rounds to increase statistical power with also a desire to explore the trajectory of 
impacts. We therefore use data for the control group and wage subsidy only treatment group to estimate treatment regressions using the following specification for outcome $Y$ for firm $i$ in period $t=3, \ldots, 12$ :

$Y_{i, t}=\alpha+\beta_{1}$ Treat $_{i} *$ Pre $_{t}+\beta_{2}$ Treat $_{i} *$ During $_{t}+\beta_{3}$ Treat $_{i} *$ Year $_{t}+\beta_{4}$ Treat $_{i} *$

Year $_{t}+\beta_{5}$ Treat $_{i} *{\text { Year } 3 \text { to }_{t}}_{t}+\sum_{s=4}^{12} \delta_{s} 1(t=s)+\theta^{\prime} X_{i}+\varepsilon_{i, t}$

Where Treat is a dummy variable for whether they got the wage subsidy treatment or not; Pre indicates the pre-treatment, post-baselines round 3, During indicates the two survey rounds 4 and 5 when the wage subsidy was in effect, and Year1, Year2, and Year3to4 indicate the survey rounds corresponding to 1 year, 2 years, and 3 to 4 years post-intervention; $1(t=s)$ are a set of survey round time dummies; $X$ is a set of controls for the randomization strata and for the baseline variables used in randomization (Bruhn and McKenzie, 2009); and the error term $\varepsilon_{i, t}$ is clustered at the firm level. The baseline controls include the baseline values of many of our key outcomes of interest, making this an Ancova specification, but where the baseline value of the outcome of interest is not in $X$, we also include it as an additional control when available. Our interest is then in the trajectory of treatment effects as given by $\beta_{2}$ to $\beta_{5}$. To account for multiple testing across periods we test the equality $\beta_{2}=\beta_{3}=\beta_{4}=\beta_{5}$ to test whether the treatment effects are stable, and $\beta_{2}=\beta_{3}=\beta_{4}=\beta_{5}=0$ to test whether we can reject that there is no treatment effect after the intervention. $\beta_{1}$ provides a placebo test, similar to a further balance test, since it uses pre-intervention data.

Note that the treatment effects we estimate are intent-to-treat effects, which is the impact of being offered the wage subsidy. This is the relevant parameter for understanding the policy impact of wage subsidy vouchers. We then turn to estimating the impact of actually hiring an additional worker in section 5.4.

\subsection{Impact on Survival}

Table 4 examines the impact of the wage subsidy on firm survival. Businesses temporarily close and then re-open again, so survival here is defined in terms of whether the owner is selfemployed at the time of the survey round, and includes the case of the owner shutting down one 
business and starting another one. ${ }^{10}$ Survival rates are reasonably high in the control group: 95.8 percent of firm owners are operating their businesses during the intervention period (one year after baseline), 88.8 percent one year after the intervention, and 83.4 percent three to four years later. However, recall that data on operating status are not available for 3 percent of firms in the three to four-year period, and these firms may have also closed. We therefore consider two other definitions of survival for robustness. The first assumes that if a firm is surveyed and found to be closed, and then attrits from future surveys, that is has remained closed. The second measure makes the assumption that all attriting firms are closed.

Figure 1 shows graphically the survival pattern round by round, and shows a clear widening of the gap between the treatment and control group over time. Table 4 shows that there is no significant impact on firm survival during the intervention, but significant impacts in all three time periods afterwards. Those that received the subsidy were 5.8 percentage points more likely to still be self-employed in our last follow-up rounds. This effect remains significant at the 10 percent level when we use either of our alternative definitions of survival. We discuss possible reasons for the survival impact in section 6, after having seen the impacts of the subsidies on employment, profitability and sales.

\subsection{Impact on Employment}

To account for this impact on survival, we code firms which are closed as having zero employment, zero profits, and zero sales in our analysis. This enables us to examine the full unconditional impact on these outcomes in a way which is not subject to selectivity concerns present in comparing only firms in operation. We later also provide comparisons of treatment and control profits and sales conditional on survival.

Figure 2 shows the time pattern of whether firms have any paid workers, and of the average number of paid workers (truncated at 5 workers, the $99^{\text {th }}$ percentile during the intervention period). We see the treatment and control group have similar employment in the baseline and survey pre-intervention, and that the treatment group hires more workers than the control during the intervention period. This gap halves in the year following the intervention but is still noticeable, and then the employment of the two groups looks similar in the last four survey

\footnotetext{
${ }^{10}$ See Appendix 4 for a discussion of alternative approaches to defining survival. All yield qualitatively similar results.
} 
rounds. A further point to note is that the control group is slowly growing employment over time, so the counterfactual is one in which some firms would be hiring even without the subsidy.

The first two panels of Table 5 examine whether this impact is significant. We see during the subsidy period there is a positive and statistically significant increase in both the likelihood of having any paid workers, and in the number of workers hired. The 14 percentage point increase in the likelihood of having any paid workers is relative to a control mean of 27 percent during this time, so the subsidy has resulted in a 52 percent increase in the likelihood of having a worker during this period. The impact on the number of paid workers is 0.20 workers, relative to a control mean of 0.48 workers, so again represents a sizeable increase in relative terms. The impact on having a paid worker remains positive and significant, at 11.1 percentage points, in the year after the intervention, but then falls to near zero and is not statistically significant in either the second or third and fourth years. The impact on the number of paid workers also shows 0.12 workers more in the year after the intervention, although this gap is not statistically significant, and then falling further over time to be near zero and not significant in the longer-term.

Figures 3 and 4 delve into the employment changes in more detail by examining the churn in employment. Figure 3 looks at the probability a firm increases or decreases the number of paid workers it has between survey rounds. We see treated firms are more likely to be adding workers during the intervention period, but less likely to be adding workers than the control group between rounds 7 and 10. Immediately after the intervention the treatment group is more likely to be reducing the number of workers it has in the six months immediately following the end of the subsidy. Figure 4 examines how many workers are being changed. We see almost all of the action is at the margin of a single worker. As the subsidy begins, the treatment group is more likely to be adding a worker, and once the subsidy ends, it is more likely to be subtracting a worker. We see that 78 percent of the control group have no change in worker numbers between rounds, so that approximately one in five control group firms are adding or subtracting workers from one round to the next. Since this is churn over a six month period, it suggests that many control group firms are able to adjust their employment rapidly.

The next two panels of Table 5 examine econometrically this churn. We see a positive and significant impact on the likelihood of adding a worker during the subsidy period, but a negative and significant impact on the likelihood of adding a worker during the period two years after the 
intervention. That is, post-subsidy, firms in the treatment group are slower to add workers during a period when firms in the control group are growing. In contrast, the impact on subtracting workers is not as dramatic as seen in Figures 3 and 4, and while positive immediately after the intervention, is not statistically significant. Graphically we see that this subtraction effect occurs in the six months immediately after the subsidy ends, and by averaging over the first year we average in also the lower chance of subtracting a worker between 6 and 12 months postintervention.

The final two panels of Table 5 consider whether the change in paid workers is changing the other two labor inputs in the business: the owner's own time, and unpaid labor. On average, firms have only 0.2 unpaid workers, and treatment has no significant impact on this number during any of our follow-up periods. The point estimates on own hours are positive, but small and not statistically significant during the intervention. The positive effect is significant for the two- and three-to-four-year follow-up periods, and reflects the greater survival of firms at this stage. Taken together, these results show that the subsidized labor is not substituting for other types of labor the business is already using, but represents a net increase in labor input during the subsidy period.

Appendix 6 explores the extent to which the wage subsidy changes which firms have workers. The evidence suggests that the new firms induced to hire an employee because of the subsidy, but who would not have hired one if they had been in the control group, are smaller and less profitable firms, and less likely to be found in Colombo. There is little selectivity on owner's characteristics. Conditional on hiring a worker, those in Colombo are more likely to have kept the worker on, with no significant differences in other firm or owner characteristics. By the time of the last survey, when we have seen the proportion of firms to have employees is similar in both groups, the some of these lower profitability treated firms no longer have a worker, while some of the lower profitability control firms have started hiring one. The result is that baseline profit levels, and other firm characteristics, are similar for the sample of treatment and control firms with workers at the time of the last survey. The one remaining difference is in terms of geography, where a smaller share of the treated firms with employees are in Colombo compared to the control group.

\subsection{Impact on Profitability and Sales}


We next examine how the wage subsidy and additional labor affected business profits and sales. There are two important issues that affect measurement of the treatment effect on these outcomes. The first, as discussed above, is the treatment impact on business survival postintervention. We consider both unconditional profits and sales (where firms not in operation are coded as having zero profits and zero sales), and conditional measures (conditioning on the business operating). Comparing outcomes for treated and control firms will only yield unbiased estimates of the impact on conditional profits and sales if survival is not selective on characteristics that predict these outcomes. We cannot reject that survival is independent of baseline characteristics (a joint test of orthogonality for the sample still self-employed in round 12 has p-value 0.562), so this may be a reasonable assumption in our case. Otherwise the conditional regressions should be viewed as descriptive, rather than causal. Second, both profits and sales have long right tails: the $99^{\text {th }}$ percentile conditional on operating is six to eight times the mean, and kurtosis values of 14 to 20 (compared to 3 for a normal distribution). We use two approaches to reduce the dependence on the top tail. The first is to consider transformations which place less weight on the top tail: the inverse-hyperbolic sine transformation of unconditional values, and the log transformation of conditional values. The second is to estimate quantile regressions. $^{11}$

Table 6 presents the estimated treatment effects on these different measures, while Figures 5 and 6 graph the quantile treatment effects for round 4 and round 12 (during the intervention, and in our last follow-up round four years later). For profits we see no significant effect during the intervention period for any of the four measures, and the quantile treatment effects on both conditional and unconditional profits are fairly constant and also not significant across the distribution. The 95 percent confidence interval for the OLS treatment effect for unconditional profits is $(-1766,3118)$, while for the $50^{\text {th }}$ percentile it is $(-1208,3140)$. This is relative to a control mean of $16603 \mathrm{LKR}$, so represents a range of $-11 \%$ to $+19 \%$. The impact on profits continues to be insignificant in all three post-intervention periods for three out of four measures in Table 6, and we can't reject the hypothesis that all treatment effects are jointly zero. The exception is the inverse hyperbolic sine transformation. This shows a positive treatment effect, which arises from the survival effect at the bottom of the distribution, with positive treatment effects for lower quantiles. Conditional on operating, this effect is not significant.

\footnotetext{
${ }^{11}$ We control for the same baseline controls in the quantile regressions as in the OLS treatment regressions.
} 
For sales we likewise see no significant treatment effect during the intervention using any of the four measures, nor using the quantile treatment effects. The 95 percent confidence interval for unconditional sales is $(-8525,+19401)$, or $(-14 \%,+32 \%)$ relative to the control mean. Like profits, the inverse-hyperbolic sine transformation of sales then shows a significant treatment effect in the post-intervention period, reflecting the impact on survival. We find a marginally significant effect on unconditional sales in year 2, and on log sales in year 1 post-intervention, but in both cases cannot reject that all treatment effects are jointly zero.

\subsection{Return to Labor}

We now can combine the impact on the number of workers with the impact on profits to obtain an estimate of the return to additional labor in these microenterprises. For comparison, we begin by using the pooled cross-sections from the control group sample to estimate for firm $i$ in periods $t=2, \ldots, 12$ :

Profits $_{i, t}=\alpha+\beta_{1} * L_{i, t}+\sum_{s=3}^{12} \delta_{s} 1(t=s)+\theta^{\prime} X_{i}+\varepsilon_{i, t}$

Where $L$ is the number of paid workers, and we control for time dummies, the variables used to form strata for randomizing, and the baseline variables used in re-randomization as before. The standard errors are clustered at the firm level. Column 1 of Table 7 shows this estimate using the unconditional level of profits as the outcome, while column 5 uses log profits (conditional on operating). We see an additional worker is significantly associated with higher profits, with firms with one more worker earning 6674 per week more profits, or 24 percent higher profits.

The standard concern with such an estimate is that there are unobserved features of the firm that are correlated with both profitability and how many workers the firm hires. For example, more productive firms may earn more and use more labor. We can control for time-invariant unobserved firm characteristics by adding firm fixed effects to equation (6). Columns 2 and 6 of Table 7 do this. Adding these fixed effects reduces the magnitude of the coefficient on labor to 4844 or 13 percent, which is still statistically significant. However, this will still overstate the return to labor if there are time-varying unobservables which lead firms to both hire more workers and be more profitable: for example, a positive demand shock may cause the firm to be able to sell more and hire more workers to meet this demand. 
Our experiment provides a estimate of the causal effect of hiring an additional worker. Since the intervention period is the only period during which we see a significant increase in the number of workers, we estimate equation (6) only during the intervention period ( $t=4$ and 5), and instrument $L$ with assignment to the wage subsidy treatment. Columns 3,4, and 7 of Table 7 then report the IV estimates, under the assumption that the wage subsidy only affects profits through the additional labor it induces. The point estimates are smaller than the fixed effects in levels, and similar in size to the fixed effects estimates in logs; however the standard errors are much larger. The point estimates suggest a return of 2400 to 3000 LKR per month per additional worker hired. In panel B we also include the other treatment groups which received wage subsidies in an effort to reduce these standard errors, and get a 95 percent confidence interval of $(-5310,+7612)$ for the impact on profits conditional on operating. Recall that the wage subsidy was 4,000 LKR per month during this time, and is not included in the measure of profit being reported by the owner. This point estimate would suggest that the net return to keeping these workers are their current wages would be negative for once the subsidy was removed.

\section{Mechanisms}

The wage subsidies induced firms to hire additional workers during the intervention period, but did not have a lasting impact on employment, nor a significant impact on profits and sales. They did however make firms more likely to survive. We examine possible explanations for these impacts in this section.

\subsection{Heterogeneity of Treatment Effects}

Our theory suggests several possible channels through which a short-term subsidy may have a lasting impact on employment. We examine the heterogeneity of treatment effects to provide some insights into whether these different channels appear to be operating in practice. To do this, we add interactions between the treatment variables and a particular baseline covariate $X$ to equation (5), along with controlling for the baseline value of $X$, and interactions between $X$ and the survey round effects. The results are then presented in Table 8, which tests for heterogeneity in the impact on the number of paid workers for different $X \mathrm{~s}$.

If the subsidy allows firm owners to learn about their management type, $\theta$, then we would expect the impacts to be greater for younger firms (where the owners have had less time to learn their type), and for firms whose owners have never hired a worker before. The first two columns of 
Table 8 show that there is no significant heterogeneity with respect to either variable. Moreover, the coefficients, indicate that that those who had hired workers before were more likely to hire workers in response to the intervention the opposite sign to what the learning-about-type theory would predict.

Column 3 of Table 8 examines heterogeneity with respect to baseline business practices. Consistent with the higher take-up seen in Table 3, we see that firm owners with more management ability were more likely to hire workers in response to the subsidy during the intervention. A one standard deviation improvement in baseline practices (5.9) is associated with a 0.19 additional worker increase during the intervention, which is significant at the five percent level. However, like the aggregate effect, this effect dissipates over time and there is no longterm effect. Our theory section noted that higher managerial ability firms might be more responsive to subsidies because of non-convexities in hiring labor. Our wage subsidy required firms to hire a full-time worker, so the margin for adjusting labor was lumpy. Better managed firms should be closer to the threshold of hiring a whole worker, so may have responded more. An alternative explanation is that firm owners with higher management ability could better understand the short-term gains possible through the subsidy.

Columns 4 and 5 of Table 8 then examine heterogeneity with respect to wealth. If firms need capital to make new workers productive, then the theory predicts that treatment effects should be higher for firms which have more access to capital. We see no heterogeneity with respect to either baseline capital stock, nor to household wealth at baseline.

Finally, in columns 6 and 7 of Table 8 we examine whether coupling the wage subsidy with additional treatments increases the impact. Column 6 considers the business training treatment. The specification here adds to equation (5) the pure treatment effects of business training in each of the time periods (not shown), and then the interactive treatment effect of receiving both the wage subsidy and business training. We cannot reject that the treatment effect is the same for those who get business training. Column 7 likewise shows there is no differential effect for those who get the savings treatment. These results are consistent with the interactions with baseline variables in showing that the lack of long-run effects don't seem to be due to lack of capital or lack of business skills.

\subsection{Survey Evidence}


Our survey data provide additional information which can help us interpret the results in Tables 5 through 8 . The fact that subsidies have a temporary effect and that there is little evidence that the increase in profits is greater than the subsidy amount suggests that labor markets work without major frictions for the micro enterprises in our sample. This picture is consistent with the view that urban informal labor markets working reasonably well. One of the advantages of experiments is that they create shocks to opportunities that allow researchers to observe how actors respond. The survey data provide details that help us understand the aggregate responses we observe in Tables 5-8.

We begin by looking at responses as they relate to key aspects of the heterogeneity examined in Table 8 .

- Learning about type and managerial ability: Did owners learn about their types, for example, did they learn about their ability to manage workers? Among those with a worker hired under the program who left, we asked which among several reasons the worker left. One option was that the owner had come to realize he was not able to properly manage the worker. Across several rounds and more than 30 such cases, this reason was only ever given once. There is a somewhat larger sample of owners who were eligible for the subsidy but never hired a worker. In October 2009, we asked these owners whether any of 12 reasons for not hiring were important in their case. Only 13.3 percent of the owners said concern about their ability to manage an employee was a reason for not hiring. The far more common responses for not hiring related to a lack of demand for labor, including that the additional employee would not be profitable (43.4 percent), that the enterprise does not require an additional employee (26.5 percent, and that the subsidy is not large enough (13.3 percent). Together, these data suggest that learning about managerial ability is not a central issue among these firms; the lack of hiring appears mainly to reflect a lack of demand for labor. However, we note that a sizeable number of respondents not hiring workers stated that they had not yet found the right employee (22.3 percent) or that they lacked the capital required to make the employee productive (27.1 percent). Hence, these data do indicate some potential role for search frictions and capital constraints. 
- Importance of access to capital: Among those not hiring workers, responses from the October 2009 survey indicate that only 40 percent would need to make a capital investment to make the additional employee profitable. Among these 40 percent, a majority (56 percent) say that a lack of capital is an important reason they did not hire anyone under the program. Note that the likelihood an owner reports that capital is a reason for not hiring is independent of either baseline profits or capital stock. Those with low profits and low capital stock are no less likely to hire under the program, though as we noted in Section 4.2 above, they are more likely to hire relatives and workers at very low rates of pay. In April 2010, we asked about the same issue with a different framing, asking how much capital would be required to make a new employee "as productive as (s)he could be." Only 7 percent of respondents said "zero" to this question, but 43 percent said 15,000 LKR or less, a level which is approximately one month's profit for the average firm. Only 22 percent said that more than 90,000 LKR - six months' average profit - would be required. Though suggesting that a lack of capital plays a role in some cases, these data are consistent with the lack of any additional effect when the savings subsidy program is combined with the wage subsidy program.

The survey data also yield some information on several other constraints suggested by theory.

- Newly-hired employees have lower productivity: This, combined with either formal or informal minimum wages might require that wage payments exceed the marginal contribution of the employee for some period of time. In those circumstances, the subsidy may induce firms to hire when they are otherwise unable to pay an interim wage that reflects the lower marginal productivity of workers during the initial period working in the firm. In April 2010, we asked owners how long they thought it would take a hired worker to become fully productive. The median response was one month, and the mean 4.1 months; 86 percent said the period would be six months or shorter, suggesting that the subsidy was long enough to fully cover the learning period for the majority of the sample. In October 2011, we asked owners how long it took for the most recent worker they had hired (if there was one) to be profitable for the enterprise. Focusing on employees hired after the subsidy period, half the owners said the employee was profitable right away, and another 38 percent said they were profitable within the first month. Only 2 percent said it 
took six months or more. Hence, the survey data do not suggest that the time taken to integrate an employee is long enough to explain the patterns we see in the data.

- The relevance of search costs: In October 2009, three months after the wage subsidy offer was made, we asked those eligible for the wage subsidies a series of questions related to search. At the time of the survey, 29 percent of those eligible had hired an employee, indicating they were able to find someone fairly quickly. Another 43 percent indicated that they had no intention of hiring an employee. ${ }^{12}$ Among the remaining 29 percent of owners who indicated they were still searching and expected to hire an employee, only 38 percent (representing 11 percent of the sample) indicated that a reason for not hiring was that they had not found the right employee. The majority indicated instead that at present the additional employee would not be profitable given the subsidy level. These data suggest that search costs are not a main constraint for the majority of owners in our sample. This conclusion is supported by data from a survey of owners of small and medium sized businesses conducted around the same time. ${ }^{13}$ In April 2009, among 160 owners with five or fewer employees, the median owner said it would take seven days to locate an employee if s/he wanted to hire one; the mean search period was 14 days. Moreover, these owners said they could hire a worker for a median of 400 LKR per day, or 2000 LKR per week, just above the average wage the employees hired under our subsidy program report being paid. That search costs are important for only a small percentage of owners of small firms is consistent with long-held views that labor markets work relatively well among informal firms. This is perhaps not surprising given that most workers are hired to do relatively routine, physical tasks. Our owners say that the sex of the worker and physical strength of the worker are the two most important characteristics of workers they consider hiring, with education the least important of the characteristics listed. Search tends to be local, with a majority of workers hired being previously known to owners and living within one kilometer of the business. ${ }^{14}$ We read these responses

\footnotetext{
12 These owners said in response to later questions that their business would not support or benefit from an additional employee. Only 11 percent of them indicated that the inability to find the right employee was a reason for not hiring.

${ }^{13}$ The SME survey was conducted in urban areas throughout Sri Lanka, but a majority of respondents come from the same urban areas in which we conducted the experiment. The survey is described in Appendix 4

${ }^{14}$ The local nature of search holds both in these data and in data from a separate survey of wage workers. In the wage worker survey, among 171 workers in firms with 4 or fewer employees, 61 percent say they knew the owner
} 
together with the response reported earlier just under a quarter of the owners eligible for the wage subsidy report not being able to find the right worker 3 months after learning of their eligibility as indicating that search frictions are important for a minority of the owners, but are not a main cause of not hiring.

Finally, the excess hiring that was created by the subsidy largely disappears within a year of withdrawing the subsidy. In most of the surveys conducted after the intervention, we asked the employers whether the employee hired under the program was still working for them, and if not, why they were not. The most common response was that the worker quit, given just over half the time. In those cases, the owner reports taking over the worker's tasks himself in 59 percent of the cases, hiring another employee 29 percent of the time, and having a family member do the work in 12 percent of the cases.

\subsection{Why was there a survival impact?}

The only long-term impact of the wage subsidies appears to be on firm survival, with no impact on paid employment, sales or profitability. The evidence presented above suggests that the survival impact is not coming through relieving labor market constraints on firms. Instead, the most likely explanation for the survival effect appears to be that the subsidy provided firms with extra profits during the intervention period, and this small amount of additional capital allowed firms to survive shocks that would otherwise shut them down. De Mel et al. (2012) show onetime grants of 10,000 and 20,000 SLK helped small firms survive. If workers earn their marginal product, then the maximum subsidy for a firm was 28,000 SLK. These firms are larger on average than those in De Mel et al. (2012), so this amount is equivalent to less than two months baseline profits. If it were to have an effect, it should therefore be for the smallest firms. Appendix 7 provides heterogeneity analysis that shows the survival effect is larger for firms with below median baseline capital and below median profitability, although results are at most significant at the 10 percent level. We therefore view this evidence as suggestive, but consistent with the survival effect coming through a credit rather than labor market channel.

\section{Discussion and Conclusions}

before beginning work, and 45 percent say they live within one kilometer of the business. The wage worker surveys is described in Appendix 4. 
Microenterprises in developing countries face many potential constraints to growth, and understanding which of these constraints are binding is crucial for designing policies to address them. Moreover, as firms with fewer than five employees are the source of livelihoods for the majority of urban workers in most low- and middle-income countries, binding constraints to their growth may have important aggregate effects on economies. This is particularly true with regard to employment growth. Compared with a larger literature on capital and entrepreneurship training, there is a paucity of research on the functioning of the informal labor markets most relevant to these firms. We use a shock to wages, implemented through temporary subsidies offered when enterprises hire new workers, to measure frictions in urban informal labor markets in Sri Lanka.

Data from the experiment suggest that labor markets function with modest frictions for these firms. The effects of the subsidy are consistent with well-functioning neo-classical labor markets. Firms respond to the subsidy by hiring additional workers, but the excess hiring dissipates completely within a year of so of the removal of the subsidies. Complementary experiments loosening credit constraints and providing entrepreneurship training do not change the effects of the temporary subsidies. We conclude that hiring frictions are not an important constraint to firm growth in our setting.

An obvious question is how much the results from this experiment generalize to the broader development context. We suspect that many characteristics of this labor market hold in most urban areas in developing countries. Workers remain unregistered and hiring is generally unregulated. The work performed by employees in small enterprises involves relatively more brawn and less creative energy. Employees are hired from local areas and there is usually a low degree of separation between employer and employee before hiring. There are other aspects of the context which are likely less usual. Our experiment coincided with the end of a long civil war in Sri Lanka, and a period of rapid growth. Compared with other low- and middle-income countries, our samples of both microentrepreneurs and wage workers show relatively high levels of generalized trust. ${ }^{15}$ How much these more distinctive features of the context drive the results

\footnotetext{
${ }^{15}$ In April 2009 surveys. 32 percent of wage workers and 27 percent of entrepreneurs said that "most people can be trusted." Though this may seem low, it compares with rates in the general population in most Sub-Saharan African and Latin American countries, where less than 20 percent of the population respond similarly. [Calculations by authors using WVS data downloaded from http://www.worldvaluessurvey.org .]
} 
is difficult to say. We would hope this might be resolved by future work examining labor market frictions in different contexts.

\section{References}

Abebe, Girum, Stefano Caria, Marcel Fafchamps, Paolo Falco, Simon Franklin, and Simon Quinn (2016). "Curse of Anonymity or Tyranny of Distance? The Impacts of Job Search Support in Urban Ethiopia" Mimeo.

Abel, Martin, Rulof Burger and Patrizio Piraino (2016) "The Value of Reference Letters - Experimental Evidence from South Africa”, Mimeo. Harvard.

Bell, Brian, Richard Blundell, and John Van Reenen (1999) "Getting the Unemployed Back to Work: The Role of Targeted Wage Subsidies." International Tax and Public Finance, 6(3): 339-60.

Bertrand, Marianne and Bruno Crépon (2016) "Teaching Labor Laws: Results from a randomized control trial in South Africa", Mimeo.

Bruhn, Miriam and David McKenzie (2009) "In Pursuit of Balance: Randomization in Practice in Development Field Experiments." American Economic Journal: Applied Economics, 1(4): 200-232.

Cohen, Alex (2016) "Constraints on Labor and Land and the Return to Microcredit and Microinsurance", Mimeo.

De Mel, Suresh, David McKenzie, and Christopher Woodruff (2008). "Returns to Capital: Results from a Randomized Experiment." Quarterly Journal of Economics 123(4): 1329-72.

De Mel, Suresh, David McKenzie, and Christopher Woodruff (2009) "Are Women more Credit Constrained? Experimental Evidence on Gender and Microenterprise Returns." American Economic Journal: Applied Economics 1(3): 1-32.

De Mel, Suresh, David McKenzie, and Christopher Woodruff (2010) "Wage Subsidies for Microenterprises." American Economic Review Papers and Proceedings, 100(2): 614-18.

De Mel, Suresh, David McKenzie, and Christopher Woodruff (2012) "One-time transfers of cash or capital have long-lasting effects on microenterprises in Sri Lanka." Science, 335(24): 962-66.

De Mel, Suresh, David McKenzie, and Christopher Woodruff (2013) "The Demand for, and Consequences of, Formalization Among Informal Firms in Sri Lanka." American Economic Journal: Applied Economics, 5(2): 122-50.

Emran, M. Shahe, AKM Mahbub Morshed and Joseph Stiglitz (2008) "Microfinance and Missing Markets", Mimeo.

Fields, Gary (1975) "Rural-Urban Migration, Urban Unemployment and Underemployment and Job-Search Activity in LDCs." Journal of Development Economics, 2: 165-87.

Freeman, Richard (2010) "Labor Regulations, Unions, and Social Protection in Developing Countries: Market Distortions or Efficient Institutions?" pp. 4657-4702 in D. Rodrik and M. Rosenzweig (eds.) Handbook of Development Economics Volume 5, Elsevier. 
Galasso, Emanuela, Martin Ravallion and Agustin Salvia (2004) "Assisting the Transition from Workfare to Work: A Randomized Experiment." Industrial and Labor Relations Review, 58(1): 128-142

Groh, Matthew, Nandini Krishnan, David McKenzie and Tara Vishwanath (2016) "Do wage subsidies provide a stepping stone to employment for recent college graduates? Evidence from a Randomized Experiment in Jordan." Review of Economics and Statistics, forthcoming.

Groh, Matthew, David McKenzie, Nour Shammout, and Tara Vishwanath (2015) "Testing the importance of search frictions and matching through a randomized experiment in Jordan", IZA Journal of Labor Economics, 4:7, 2015

Hardy, Morgan and Jamie McCasland (2015) "Are Small Firms Labor Constrained? Experimental Evidence from Ghana." Mimeo.

Imbens, Guido and Donald Rubin (2015) Causal Inference for Statistics, Social, and Biomedical Sciences: An Introduction. Cambridge University Press, New York, NY.

Jovanovic, Boyan (1982) "Selection and the evolution of industry." Econometrica 50(3): $649-70$.

Levinsohn, James, Neil Rankin, Gareth Roberts. and Volker Schöer (2014) "Wage subsidies to address youth unemployment in South Africa: Evidence from a randomised control trial", Mimeo.

Lucas, Robert (1978) "On the size distribution of business firms." Bell Journal of Economics 9(2): 508-23.

McKenzie, David (2012) "Beyond baseline and follow-up: The case for more $\mathrm{T}$ in experiments." Journal of Development Economics, 99(2): 210-21.

Mortensen, Dale, and Christopher Pissarides, (1994) "Job Creation and Job Destruction in the Theory of Unemployment."' Review of Economic Studies 61, 397-415.

Rauch, James (1991) "Modelling the Informal Sector Formally." Journal of Development Economics, 35: 33-47.

Rosenzweig, Mark (1988) "Labor markets in low-income countries", pp. 713-62 in H. Chenery and T.N. Srinivasan (eds.) Handbook of Development Economics. North-Holland: Amsterdam

Stiglitz, Joseph (1974) "Alternative Theories of Wage Determination and Unemployment in LDC's: The Labor Turnover Model”, Quarterly Journal of Economics 88(2): 194-227.

Zenou, Yves (2008) "Job Search and Mobility in Developing Countries: Theory and Policy Implications.” Journal of Development Economics, 86: 336-35. 
Figure 1: Impact on Firm Survival over Time

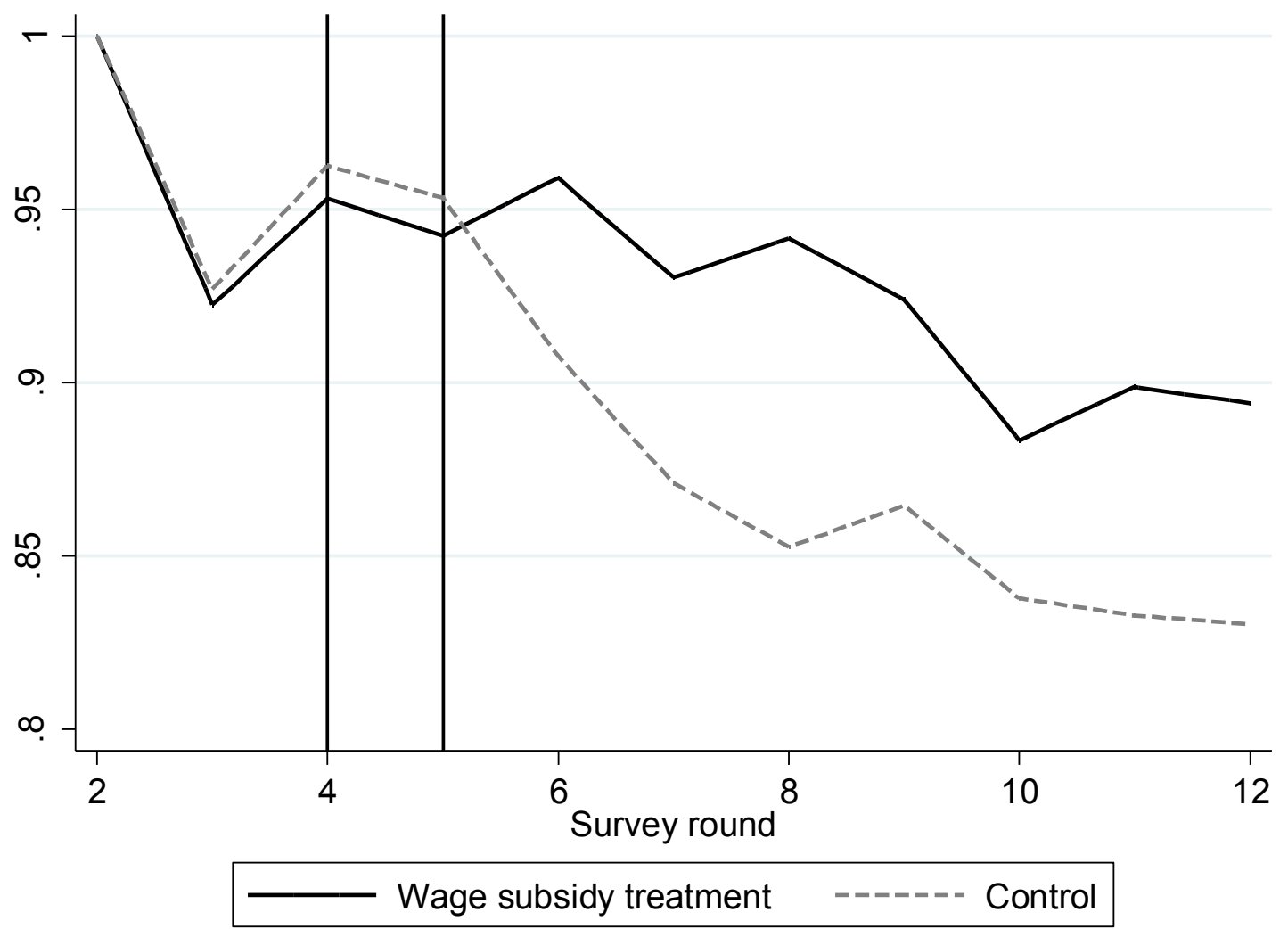

Notes: vertical lines indicate period during which wage subsidy was in effect. Round 2 is baseline for half the sample and first follow-up for the other half. 
Figure 2: Impact on Employment
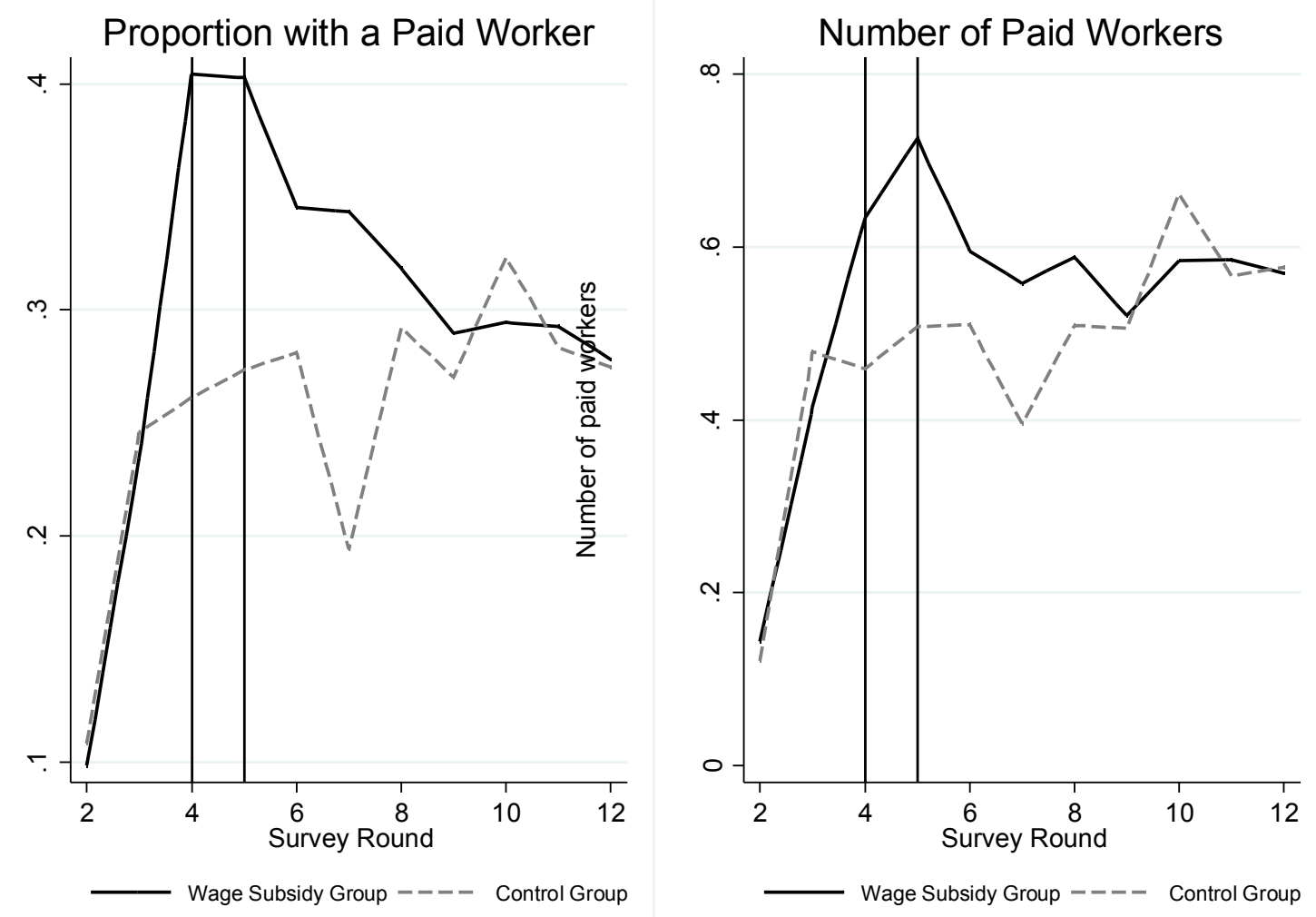

Notes: vertical lines show intervention period. Number of workers truncated at 5 workers. Round 2 is baseline for half the sample and first follow-up for the other half. 
Figure 3: Employment Churn
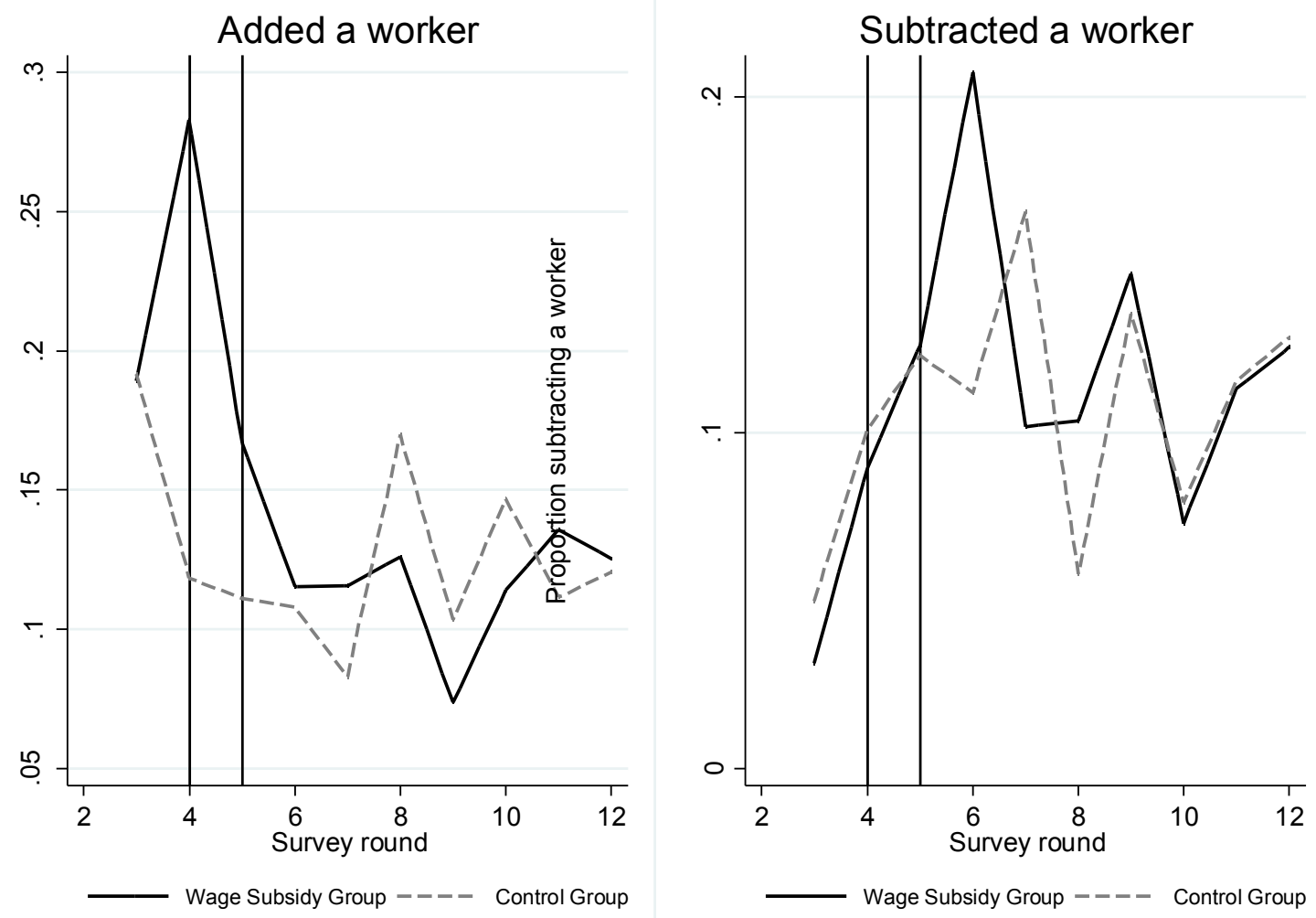

Notes: vertical lines show intervention period. Addition and subtraction of workers are defined in terms of changes in the total number of paid workers the firm has between one survey round and the next. 
Figure 4: Churn in the Number of Workers
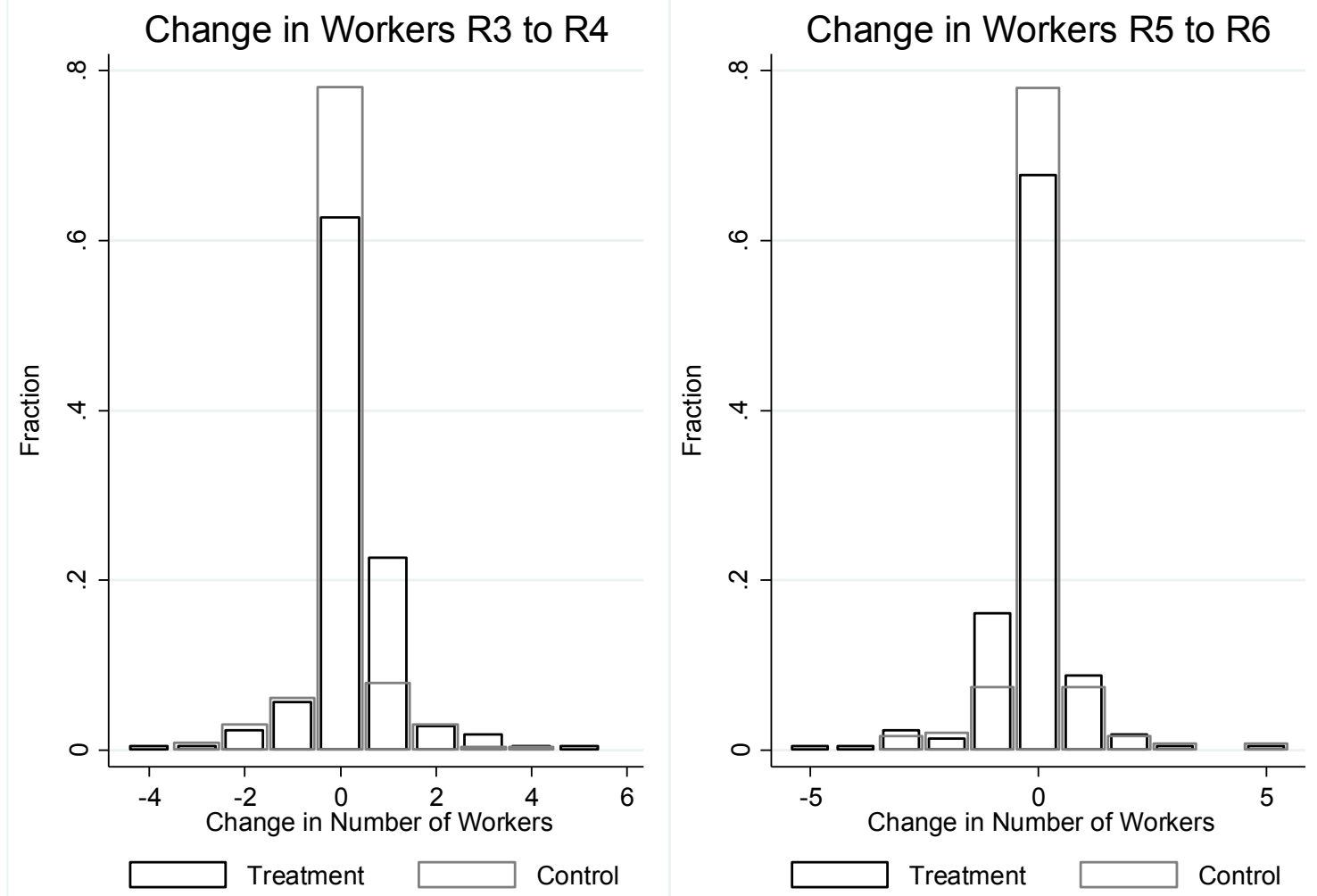

Notes: R3 to R4 is the change in the number of workers between the last pre-intervention survey and first survey during the wage subsidy. R5 to R6 is the change in the number of workers between the last survey during the intervention and first survey after the intervention. 
Figure 5: Quantile Treatment Effects on Profits in Round 4 (During Intervention) and Round 12 (4 years later)
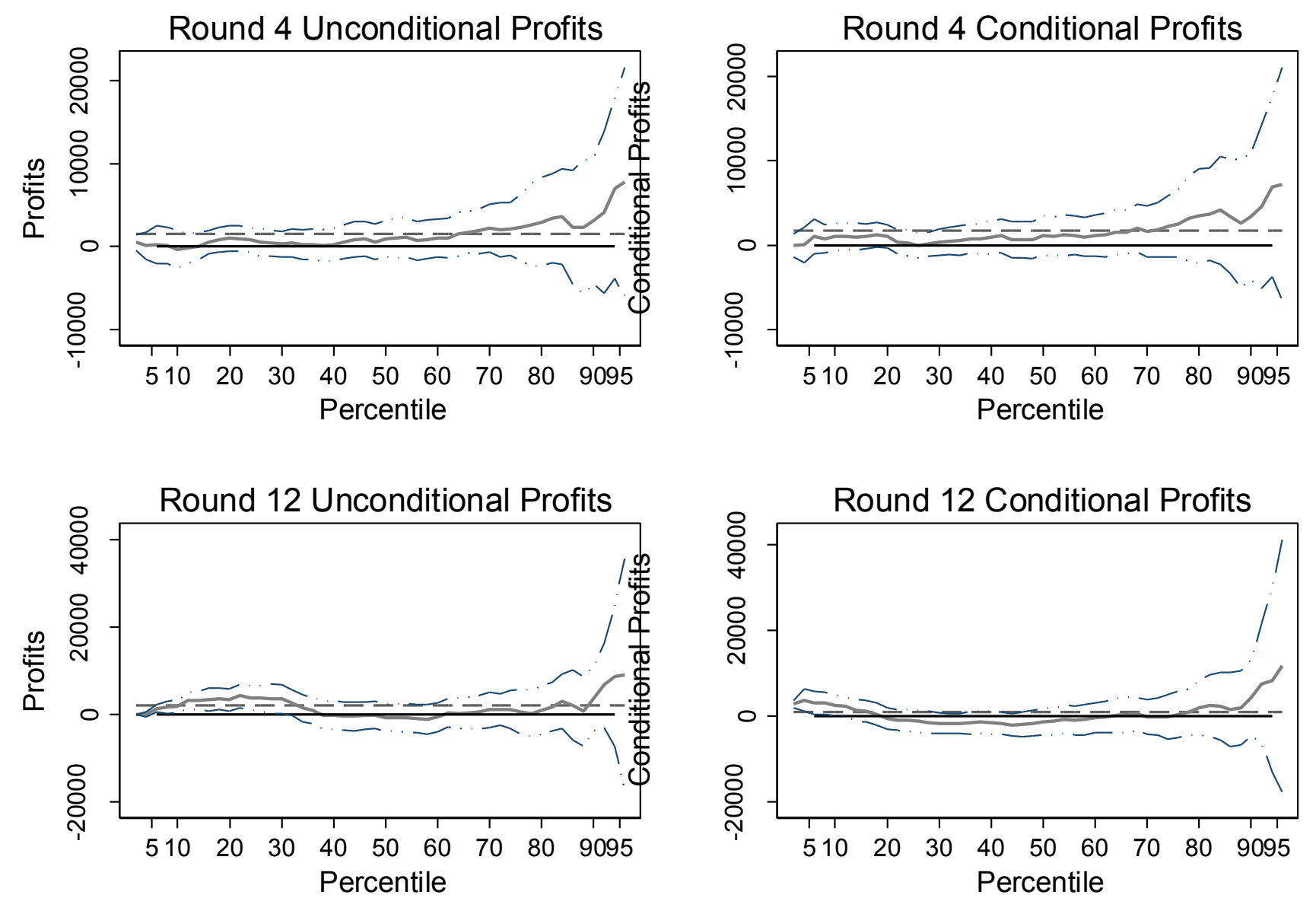

Notes: solid line shows quantile treatment effects, with $95 \%$ confidence interval around it. Dashed line indicates OLS treatment effect. Quantile regressions control for baseline profits, randomization strata, and the set of re-randomized variables. Unconditional profits include zeros for firms not operating; conditional profits

are conditional

on

the

business

still

operating. 
Figure 6: Quantile Treatment Effects on Sales in Round 4 (During Intervention) and Round 12 (4 years later)
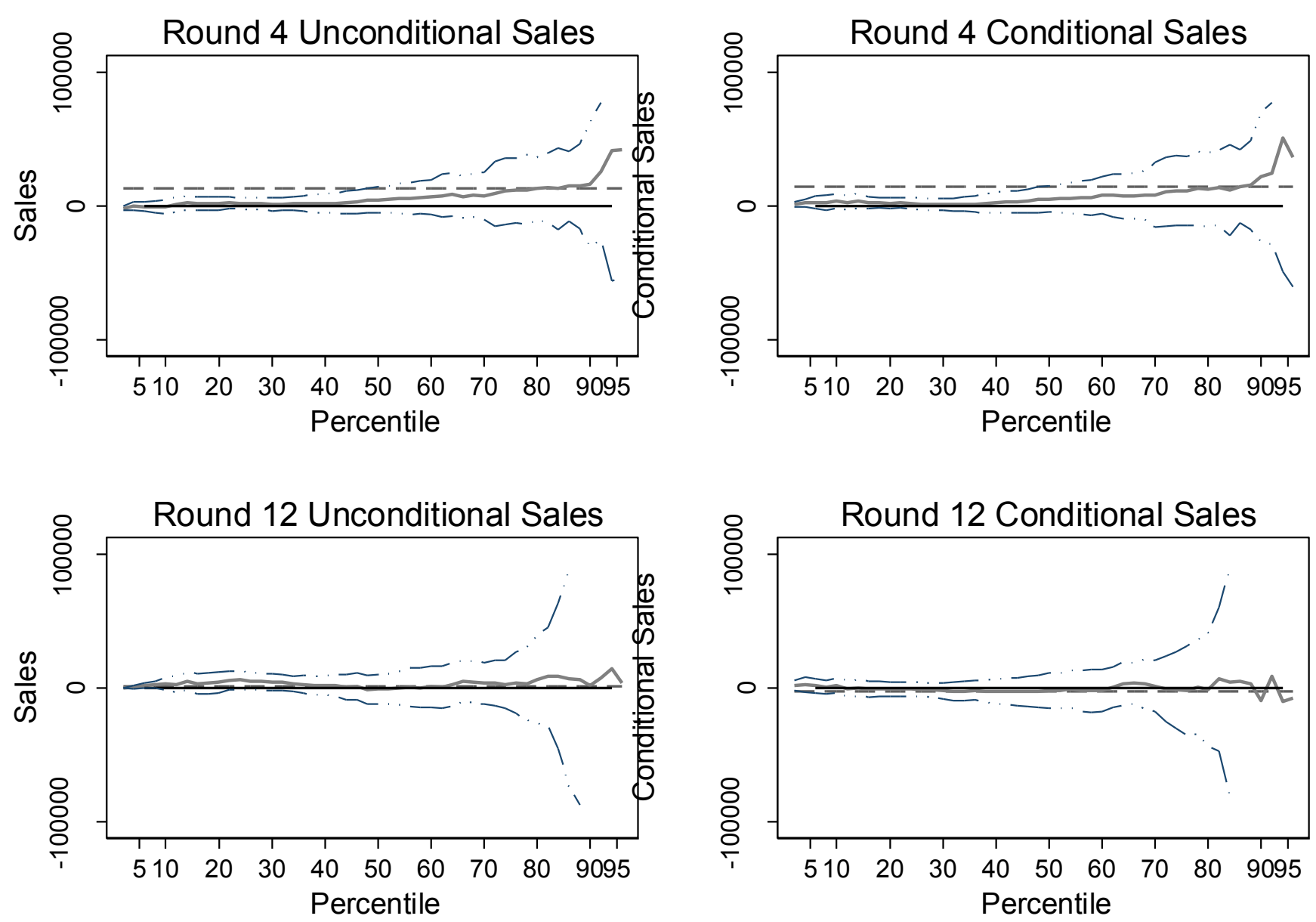

Notes: solid line shows quantile treatment effects, with 95\% confidence interval around it. Dashed line indicates OLS treatment effect. Quantile regressions control for baseline profits, randomization strata, and the set of re-randomized variables. Unconditional profits include zeros for firms not operating; conditional profits

are

conditional

on

the

business

still

operating. 
Table 1: Balance at Baseline and Endline

\begin{tabular}{|c|c|c|c|c|c|c|c|c|}
\hline & \multicolumn{3}{|c|}{ Full Sample } & \multirow{2}{*}{$\begin{array}{l}\text { Normalized } \\
\text { Difference }\end{array}$} & \multicolumn{3}{|c|}{ Present in Round 12} & \multirow{2}{*}{$\begin{array}{c}\text { Normalized } \\
\text { Difference }\end{array}$} \\
\hline & Control & Treatment & $\mathrm{p}$-value & & Control & Treatment & $p$-value & \\
\hline \multicolumn{9}{|l|}{ Re-randomized Variables } \\
\hline Number of Paid Workers & 0.19 & 0.16 & 0.498 & -0.059 & 0.18 & 0.13 & 0.255 & -0.092 \\
\hline Education (Years) & 10.35 & 10.25 & 0.641 & -0.040 & 10.35 & 10.23 & 0.604 & -0.050 \\
\hline Raven Test Score & 3.34 & 3.34 & 0.983 & 0.002 & 3.31 & 3.28 & 0.874 & -0.015 \\
\hline Digitspan Recall Score & 6.42 & 6.36 & 0.628 & -0.042 & 6.43 & 6.39 & 0.786 & -0.031 \\
\hline Total Assets & 239893 & 250563 & 0.768 & 0.026 & 246815 & 248026 & 0.771 & 0.003 \\
\hline Total Assets<1500LKR & 0.06 & 0.02 & 0.062 & -0.164 & 0.06 & 0.02 & 0.022 & -0.218 \\
\hline Total Assets $>935000$ LKR & 0.05 & 0.06 & 0.864 & 0.015 & 0.06 & 0.06 & 0.733 & 0.005 \\
\hline Monthly Profits & 13862 & 14552 & 0.509 & 0.057 & 13916 & 14485 & 0.448 & 0.047 \\
\hline Profit Data Missing & 0.03 & 0.02 & 0.348 & -0.082 & 0.03 & 0.02 & 0.486 & -0.058 \\
\hline Monthly Profits $<2000 L K R$ & 0.06 & 0.03 & 0.179 & -0.118 & 0.06 & 0.03 & 0.240 & -0.099 \\
\hline Monthly Profits $>30000$ LKR & 0.04 & 0.06 & 0.257 & 0.098 & 0.04 & 0.06 & 0.342 & 0.074 \\
\hline Business Practices Score & 8.27 & 8.76 & 0.343 & 0.082 & 8.32 & 8.78 & 0.429 & 0.079 \\
\hline From booster sample & 0.52 & 0.53 & 0.841 & 0.017 & 0.53 & 0.54 & 0.906 & 0.032 \\
\hline \multicolumn{9}{|l|}{ Stratification Variables } \\
\hline Retail Sector & 0.39 & 0.38 & 0.857 & -0.016 & 0.39 & 0.39 & 0.974 & -0.001 \\
\hline Colombo & 0.47 & 0.44 & 0.436 & -0.068 & 0.46 & 0.41 & 0.317 & -0.105 \\
\hline Kandy & 0.47 & 0.48 & 0.893 & 0.012 & 0.48 & 0.50 & 0.736 & 0.041 \\
\hline \multicolumn{9}{|l|}{ Additional Variables } \\
\hline Any paid worker at baseline & 0.12 & 0.10 & 0.388 & -0.075 & 0.12 & 0.08 & 0.119 & -0.129 \\
\hline Monthly Sales & 41175 & 52435 & 0.048 & 0.171 & 42079 & 52142 & 0.070 & 0.152 \\
\hline Owner's Age & 35.43 & 35.16 & 0.644 & -0.040 & 35.34 & 35.37 & 0.995 & 0.006 \\
\hline Business is Registered for Taxes & 0.31 & 0.32 & 0.827 & 0.019 & 0.31 & 0.32 & 0.916 & 0.008 \\
\hline Weekly hours worked & 57.94 & 59.31 & 0.379 & 0.076 & 58.23 & 58.55 & 0.940 & 0.018 \\
\hline Sample Size & 286 & 250 & & & & 262 & 230 & \\
\hline Joint orthogonality $p$-value & & & 0.734 & & & & 0.649 & \\
\hline
\end{tabular}

Note: present in round 12 denotes information on whether they have a paid worker is available in the last survey round. 
Table 2: Data Availability by Treatment Status and Timing

\begin{tabular}{|c|c|c|c|c|c|}
\hline & \multirow{2}{*}{$\begin{array}{l}\text { Before } \\
\text { Subsidy }\end{array}$} & \multirow{2}{*}{$\begin{array}{l}\text { During } \\
\text { Subsidy }\end{array}$} & \multicolumn{3}{|c|}{ After Subsidy } \\
\hline & & & Year1 & Year2 & Year3+ \\
\hline \multicolumn{6}{|c|}{ Panel A: Data on Operating Status Available } \\
\hline Control Group & 0.958 & 0.951 & 0.983 & 0.986 & 0.976 \\
\hline Wage Subsidy Treatment & 0.980 & 0.956 & 0.976 & 0.964 & 0.972 \\
\hline p-value & 0.148 & 0.787 & 0.596 & 0.099 & 0.799 \\
\hline \multicolumn{6}{|c|}{ Panel B: Data on Having a Paid Worker Available } \\
\hline Control Group & 0.839 & 0.951 & 0.965 & 0.962 & 0.962 \\
\hline Wage Subsidy Treatment & 0.888 & 0.956 & 0.948 & 0.920 & 0.956 \\
\hline p-value & 0.102 & 0.787 & 0.333 & 0.040 & 0.748 \\
\hline \multicolumn{6}{|c|}{ Panel C: Data on Profits Available } \\
\hline Control Group & 0.808 & 0.944 & 0.965 & 0.965 & 0.962 \\
\hline Wage Subsidy Treatment & 0.832 & 0.956 & 0.944 & 0.920 & 0.956 \\
\hline p-value & 0.467 & 0.529 & 0.241 & 0.024 & 0.748 \\
\hline
\end{tabular}

Notes: Before Subsidy refers to round 3 data between baselines and intervention. P-value is from t-test of equality of response rates between control and wage subsidy treatment. Proportions shown indicate that data are available for at least one survey round during the specified timing window. Profits and Workers are set to zero for firms which are closed down. 
Table 3: Correlates of Take-up

\begin{tabular}{|c|c|c|c|c|c|c|}
\hline \multirow{2}{*}{$\overline{\text { Retail }}$} & \multicolumn{3}{|c|}{ Wage Subsidy Only Sample } & \multicolumn{3}{|c|}{ Any Wage Subsidy Treatment } \\
\hline & -0.084 & & $-0.102 *$ & 0.001 & & -0.016 \\
\hline & $(0.055)$ & & $(0.055)$ & $(0.030)$ & & $(0.030)$ \\
\hline \multirow[t]{2}{*}{ Colombo } & $-0.196 * *$ & & -0.134 & $-0.210 * * *$ & & $-0.155^{* * *}$ \\
\hline & $(0.092)$ & & $(0.094)$ & $(0.054)$ & & $(0.055)$ \\
\hline \multirow[t]{2}{*}{ Kandy } & -0.067 & & -0.037 & $-0.145^{* * *}$ & & $-0.117 * *$ \\
\hline & $(0.091)$ & & $(0.092)$ & $(0.054)$ & & $(0.054)$ \\
\hline \multirow[t]{2}{*}{ Formally registered } & -0.006 & & -0.014 & 0.030 & & 0.016 \\
\hline & $(0.060)$ & & $(0.057)$ & $(0.031)$ & & (0.031) \\
\hline \multirow[t]{2}{*}{ Any paid worker at baseline } & 0.089 & & 0.042 & 0.034 & & 0.004 \\
\hline & $(0.086)$ & & $(0.083)$ & $(0.046)$ & & $(0.046)$ \\
\hline \multirow[t]{2}{*}{ Above median assets } & -0.018 & & -0.038 & 0.004 & & -0.019 \\
\hline & $(0.056)$ & & $(0.053)$ & $(0.030)$ & & $(0.030)$ \\
\hline \multirow[t]{2}{*}{ Firm five years or younger } & 0.067 & & 0.066 & 0.026 & & 0.025 \\
\hline & $(0.054)$ & & $(0.053)$ & $(0.029)$ & & $(0.030)$ \\
\hline \multirow[t]{2}{*}{ Owner's education (years) } & & $0.020^{*}$ & 0.016 & & $0.014^{* *}$ & $0.012^{*}$ \\
\hline & & $(0.011)$ & $(0.011)$ & & $(0.006)$ & $(0.006)$ \\
\hline \multirow[t]{2}{*}{ Baseline business practice index } & & $0.011 * * *$ & $0.011^{* * *}$ & & $0.011 * * *$ & $0.010 * * *$ \\
\hline & & $(0.004)$ & $(0.004)$ & & $(0.002)$ & $(0.003)$ \\
\hline \multirow{2}{*}{ Owner's age } & & -0.002 & 0.001 & & 0.001 & 0.002 \\
\hline & & $(0.004)$ & $(0.004)$ & & $(0.002)$ & $(0.002)$ \\
\hline Sample Size & 250 & 250 & 250 & 843 & 843 & 842 \\
\hline Pseudo-R2 & 0.044 & 0.050 & 0.083 & 0.020 & 0.036 & 0.047 \\
\hline
\end{tabular}

Notes: coefficients are marginal effects from probit estimation. Robust standard errors in parentheses. ${ }^{*}, * *$, and ${ }^{* * *}$ denote significance at the 10,5 , and 1 percent levels respectively. 
Table 4: Impact on Firm Survival

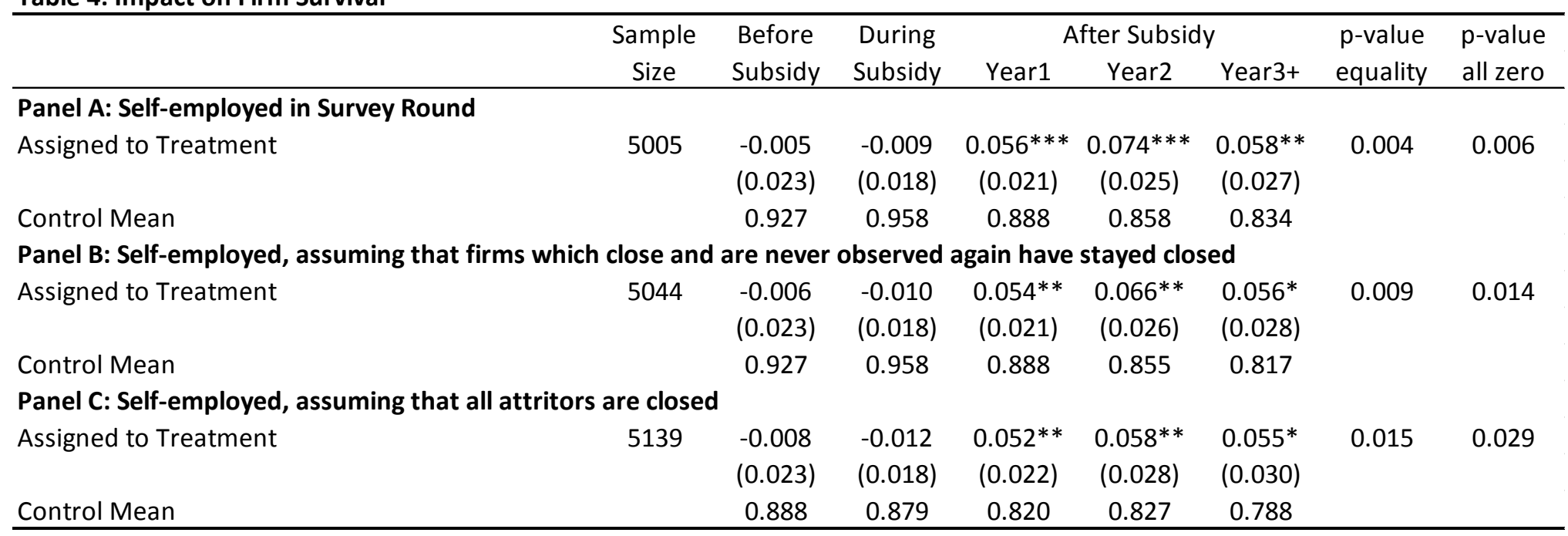

Notes: robust standard errors in parentheses, clustered at the firm level. All regressions control for randomization strata, variables used for re-randomization, and contain survey round dummies.

$*, * *, * * *$ indicate significance at the 10,5 , and 1 percent levels respectively.

$\mathrm{p}$-values are for test that the treatment effect is equal in the during, year 1 , year 2 , and years 3 to 4 periods; and that the treatment effect is zero in all four periods. 


\begin{tabular}{|c|c|c|c|c|c|c|c|c|}
\hline & \multirow[b]{2}{*}{ Sample size } & \multirow{2}{*}{$\begin{array}{l}\text { Before } \\
\text { Subsidy }\end{array}$} & \multirow{2}{*}{$\begin{array}{l}\text { During } \\
\text { Subsidy }\end{array}$} & \multicolumn{3}{|c|}{ After Subsidy } & \multirow{2}{*}{$\begin{array}{l}\text { p-value } \\
\text { equality }\end{array}$} & \multirow{2}{*}{$\begin{array}{l}p \text {-value } \\
\text { all zero }\end{array}$} \\
\hline & & & & Year1 & Year2 & Year3+ & & \\
\hline \multicolumn{9}{|c|}{ Panel A: Number of Paid Workers } \\
\hline \multirow[t]{2}{*}{ Assigned to Treatment } & 4824 & -0.077 & $0.204^{* * *}$ & 0.124 & 0.047 & -0.023 & 0.043 & 0.027 \\
\hline & & $(0.082)$ & $(0.075)$ & $(0.078)$ & $(0.080)$ & $(0.084)$ & & \\
\hline Control Mean & & 0.48 & 0.48 & 0.45 & 0.51 & 0.60 & & \\
\hline \multicolumn{9}{|l|}{ Panel B: Any Paid Worker } \\
\hline \multirow[t]{2}{*}{ Assigned to Treatment } & 4824 & -0.014 & $0.140 * * *$ & $0.111 * * *$ & 0.024 & -0.002 & 0.000 & 0.000 \\
\hline & & $(0.036)$ & $(0.035)$ & $(0.034)$ & $(0.035)$ & $(0.032)$ & & \\
\hline Control Mean & & 0.25 & 0.27 & 0.24 & 0.28 & 0.29 & & \\
\hline \multicolumn{9}{|c|}{ Panel C: Added a Worker Between Survey Rounds } \\
\hline \multirow[t]{2}{*}{ Assigned to Treatment } & 4614 & -0.008 & $0.109 * * *$ & 0.015 & $-0.041 * *$ & -0.003 & 0.000 & 0.000 \\
\hline & & $(0.036)$ & $(0.024)$ & $(0.020)$ & $(0.020)$ & $(0.017)$ & & \\
\hline Control Mean & & 0.19 & 0.11 & 0.10 & 0.14 & 0.13 & & \\
\hline \multicolumn{9}{|c|}{ Panel D: Subtracted a Worker Between Survey Rounds } \\
\hline \multirow[t]{2}{*}{ Assigned to Treatment } & 4614 & -0.022 & -0.007 & 0.017 & 0.028 & -0.005 & 0.413 & 0.546 \\
\hline & & $(0.016)$ & $(0.019)$ & $(0.022)$ & $(0.020)$ & $(0.016)$ & & \\
\hline Control Mean & & 0.05 & 0.11 & 0.14 & 0.10 & 0.11 & & \\
\hline \multicolumn{9}{|c|}{ Panel E: Own Hours Worked in the Business } \\
\hline \multirow[t]{2}{*}{ Assigned to Treatment } & 4882 & -0.580 & 0.664 & 2.919 & $3.932 *$ & $4.440 * *$ & 0.423 & 0.189 \\
\hline & & $(2.261)$ & $(1.910)$ & $(1.978)$ & $(2.076)$ & $(1.960)$ & & \\
\hline Control Mean & & 47.3 & 51.3 & 44.0 & 45.0 & 42.8 & & \\
\hline \multicolumn{9}{|c|}{ Panel F: Number of Unpaid Workers in Business } \\
\hline \multirow[t]{2}{*}{ Assigned to Treatment } & 4785 & -0.045 & 0.008 & -0.026 & 0.022 & 0.008 & 0.646 & 0.776 \\
\hline & & $(0.047)$ & $(0.035)$ & $(0.044)$ & $(0.038)$ & $(0.037)$ & & \\
\hline Control Mean & & 0.21 & 0.18 & 0.26 & 0.17 & 0.22 & & \\
\hline
\end{tabular}

Notes: robust standard errors in parentheses, clustered at the firm level. All regressions control for randomization strata, variables used for re-randomization, the baseline value (except for panels C and D on churn), and contain survey round dummies. ${ }^{*}, * * * * *$ indicate significance at the 10,5 , and 1 percent levels respectively.

Regressions are unconditional, and assign zero to the outcome for firms not operating.

$p$-values are for test that the treatment effect is equal in the during, year 1 , year 2, and years 3 to 4 periods; and that the treatment effect is zero in all four periods. 
Table 6: Impact on Profits and Sales

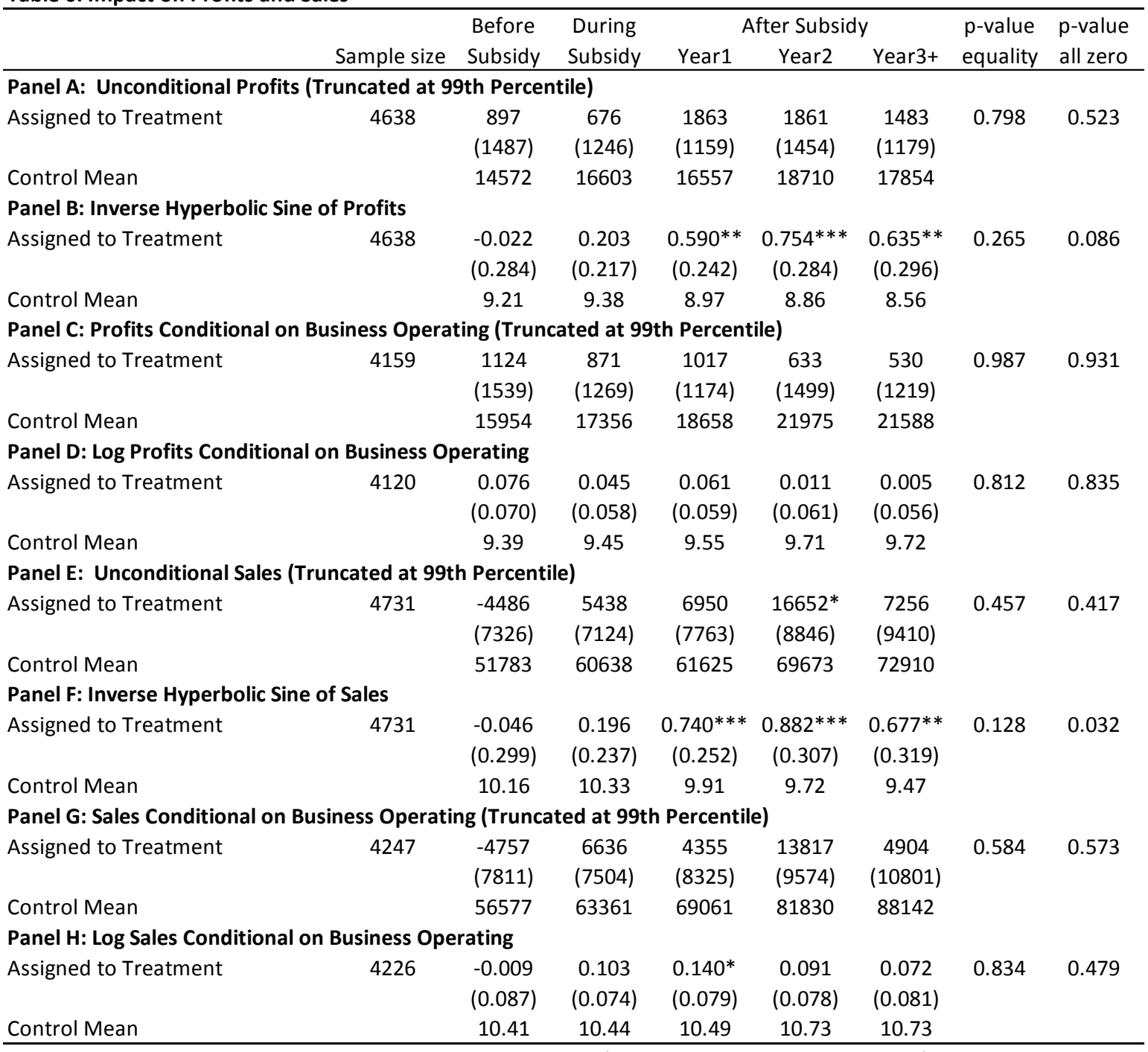

Notes: robust standard errors in parentheses, clustered at the firm level. All regressions control for randomization strata, variables used for re-randomization, the baseline value (except for panels $C$ and $D$ on churn), and contain survey round dummies. $*, * *, * *$ indicate significance at the 10,5 , and 1 percent levels respectively. $p$-values are for test that the treatment effect is equal in the during, year 1, year 2, and years 3 to 4 periods; and that the treatment effect is zero in all four periods. 


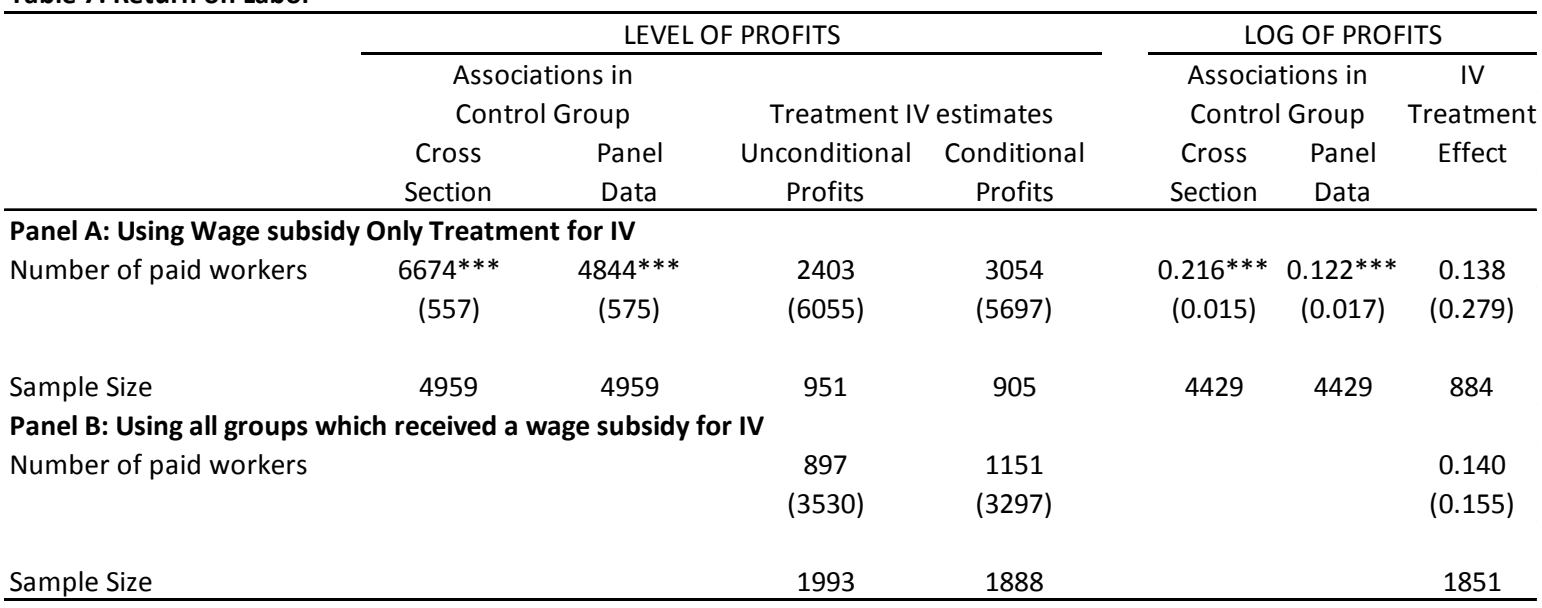

Notes: robust standard errors in parentheses, clustered at the firm level.

$*, * *, * * *$ indicate significance at the 10,5 , and 1 percent levels respectively.

Regressions control for time fixed effects, randomization strata, and controls used in re-randomization.

Columns 1, 2, 5, and 6 use control group only. Columns 3,4 and 7 use wage subsidy only and control groups in panel A and all groups receiving a wage subsidy in panel B. 
Table 8: Heterogeneity in Impact on Number of Employees

\begin{tabular}{|c|c|c|c|c|c|c|c|}
\hline \multirow[t]{2}{*}{ Before Subsidy } & -0.178 & -0.068 & -0.127 & -0.078 & -0.111 & -0.087 & -0.073 \\
\hline & $(0.114)$ & $(0.062)$ & $(0.146)$ & $(0.112)$ & $(0.123)$ & $(0.083)$ & $(0.083)$ \\
\hline \multirow[t]{2}{*}{ During Subsidy } & 0.102 & $0.170 * *$ & -0.079 & 0.136 & 0.155 & $0.191 * *$ & $0.210 * * *$ \\
\hline & $(0.107)$ & $(0.069)$ & $(0.128)$ & $(0.096)$ & $(0.115)$ & $(0.075)$ & $(0.076)$ \\
\hline \multirow[t]{2}{*}{ Year 1 After } & 0.133 & 0.105 & -0.135 & 0.059 & 0.075 & 0.112 & $0.129 *$ \\
\hline & $(0.100)$ & $(0.082)$ & $(0.147)$ & $(0.106)$ & $(0.126)$ & $(0.079)$ & $(0.078)$ \\
\hline \multirow[t]{2}{*}{ Year 2 After } & 0.021 & -0.010 & -0.137 & -0.068 & -0.025 & 0.035 & 0.052 \\
\hline & $(0.105)$ & $(0.081)$ & $(0.148)$ & (0.109) & $(0.136)$ & $(0.081)$ & $(0.081)$ \\
\hline \multirow[t]{2}{*}{ Years 3-4 After } & -0.043 & -0.046 & -0.046 & -0.069 & -0.072 & -0.032 & -0.017 \\
\hline & $(0.106)$ & $(0.089)$ & $(0.145)$ & $(0.121)$ & $(0.134)$ & $(0.084)$ & $(0.084)$ \\
\hline \multirow[t]{2}{*}{ Interaction with } & Young & previously & business & above & low household & also assigned & also assigned \\
\hline & firm & hired & practices & median capital & wealth & business training & savings treatment \\
\hline \multirow[t]{2}{*}{ Before Subsidy*Interaction } & 0.224 & 0.026 & 0.006 & 0.016 & 0.051 & 0.090 & 0.068 \\
\hline & (0.159) & $(0.258)$ & $(0.014)$ & $(0.166)$ & $(0.163)$ & $(0.145)$ & (0.139) \\
\hline \multirow[t]{2}{*}{ During Subsidy*Interaction } & 0.227 & 0.215 & $0.033 * *$ & 0.145 & 0.078 & -0.016 & 0.040 \\
\hline & $(0.149)$ & $(0.228)$ & $(0.014)$ & $(0.152)$ & $(0.150)$ & $(0.123)$ & $(0.131)$ \\
\hline \multirow[t]{2}{*}{ Year 1 After*Interaction } & -0.019 & 0.120 & $0.030 * *$ & 0.144 & 0.082 & -0.071 & 0.089 \\
\hline & $(0.158)$ & $(0.209)$ & $(0.015)$ & $(0.157)$ & $(0.156)$ & (0.139) & $(0.142)$ \\
\hline \multirow[t]{2}{*}{ Year 2 After*Interaction } & 0.057 & 0.265 & 0.022 & 0.255 & 0.120 & 0.089 & 0.045 \\
\hline & $(0.162)$ & $(0.235)$ & $(0.016)$ & $(0.161)$ & $(0.164)$ & (0.139) & $(0.148)$ \\
\hline \multirow[t]{2}{*}{ Years 3-4 After*Interaction } & 0.045 & 0.133 & 0.002 & 0.105 & 0.083 & 0.059 & 0.066 \\
\hline & $(0.172)$ & $(0.227)$ & $(0.016)$ & (0.166) & (0.169) & $(0.135)$ & $(0.155)$ \\
\hline Sample Size & 4824 & 4824 & 4824 & 4824 & 4824 & 8742 & 8433 \\
\hline P-value to test interactions all zero & 0.377 & 0.788 & 0.063 & 0.565 & 0.989 & 0.677 & 0.986 \\
\hline
\end{tabular}

Notes: robust standard errors in parentheses, clustered at the firm level. All regressions control for randomization strata, variables used for re-randomization and survey round. Columns 1 to 5 also control for baseline value of interacting variable and interaction between this interacting variable and survey round. Columns 6 and 7 also control for business training and savings treatment effects respectively.

$*, * *, * * *$ indicate significance at the 10,5 , and 1 percent levels respectively.

Young firms are less than 5 years at baseline; low household wealth is based on a principal component of household assets. See appendix 4. 


\section{For Online Publication}

\section{Appendix 1: Timeline}

April 2008 Round 1 - Screening Survey and Baseline I

October 2008: Round 2- Booster Sample and Baseline II

April 2009: Round 3

August 2009: Wage Subsidies Begin

October 2009: Round 4 (During Intervention)

April 2010: Round 5 (During Intervention)

May 2010: Wage Subsidies End

October 2010: Round 6

April 2011: Round 7

October 2011: Round 8

April 2012: Round 9

October 2012: Round 10

April 2013: Round 11

April 2014: Round 12

Supplementary Treatments:

Savings Treatment began November 2008, ended August 2009

Business Training Treatment: June-July 2009

\section{Appendix 2: Further Details on Sampling}

About half of our sample for this project comes from a larger panel survey which is representative of all urban areas in Sri Lanka outside the northern province. From this panel survey, we selected 717 male self employed workers with 2 or fewer paid employees in urban areas in Sri Lanka: Colombo, Kandy and the Galle-Matara area. This part of the sample was constructed through a listing exercise conducted in early 2008. We selected a total of 18 Division Secretariat (D.S.) Divisions in the three urban areas. Within each D.S. Division we then selected 10 (in Colombo and Kandy) or 5 (in Galle/ Matara) Grama Niladhara (GN) divisions and listed 
50 households starting from a random point. ${ }^{16}$ Because we needed a larger sample for the interventions, in October 2008 we selected a set of GNs neighboring those in the original panel survey. We used a similar screening survey to identify male self-employed workers with fewer than 2 paid employees, boosting the sample by 816 individuals. Because of the way they are constructed, both subsamples are representative of the areas from which they are taken. However, there are some differences in the manner of constructing them, so we add a control for the enterprises in the booster sample in each of the regressions. ${ }^{17}$

\section{Appendix 3: Details of Supplementary Interventions}

Savings Intervention: In November 2008 we notified those assigned to the savings treatment that they had been selected to participate in a program designed to encourage them to build savings balances. The participants were not told about the other two interventions in November even if they had been assigned to one of the other two treatments. As a part of the savings incentive program, we offered to make the initial deposit in a savings account at the National Savings Bank (NSB) and then to match deposits made into that account up to a certain limit each month and at a pre-announced match rate. The account would remain 'locked' until 1 August 2009. The initial match rate was set at 50 percent for deposits of up to 1000 Sri Lankan Rupees (LKR) ${ }^{18}$ made by the end of December. The match rate was kept at 50 percent through July, but the maximum amount we would match was increased to 2000 LKR in January and to 4000 LKR in May, 2009. In July, we raised the match rate to $100 \%$ and the maximum to 5000 LKR. Finally, just before the accounts were unlocked, we added 5000 LKR to every account, regardless of previous deposit patterns. The participants received regular passbooks for the accounts, and deposits could be made at any NSB branch. But the accounts were all opened through a single branch in Gampola so that the branch manager there was able to ensure that money was withdrawn before 1 August only if the participant faced an emergency situation. After the accounts were unlocked on 1 August, the participants were free to move the accounts to any

\footnotetext{
${ }^{16}$ The G.N. Division is the smallest of the four administrative levels in Sri Lanka: Provinces (9), Districts (25), Divisional Secretariat (DS) Divisions (324), and Grama Niladhari (GN) Divisions (14,008).

${ }^{17} \mathrm{We}$ find no differences in the operating characteristics of the enterprises (sales, profits, etc.) but the owners in the original sample have about a half year less schooling and have been in business for about three-quarters of a year longer.

${ }^{18} 1000$ LKR was approximately US $\$ 8.75$ in mid-2009, $\$ 8.85$ in mid-2010, $\$ 9.14$ in mid-2011, and $\$ 7.49$ in mid2012.
} 
NSB branch, or to withdraw the money. At that point, we lost access the administrative data, and hence are unable to track when money was withdrawn.

Training Intervention: This treatment was a training program based on the International Labor Organization's Improve Your Business (IYB) program. IYB is a five day program intended to generate growth in microenterprises. The modules covered are marketing, buying, costing, stock control, record keeping, and financial planning. We asked that the training also include additional material on hiring and managing employees, as employment generation is a key outcome of interest in the project. The training was provided by the Sri Lankan Business Development Centre (SLBDC), ${ }^{19}$ a Sri Lankan non-profit training institution established in 1984. SLBDC is the most experienced provider of ILO entrepreneurship programs in Sri Lanka, having offered the first training on the island in 2001. All of the SLBDC training staff involved in the project were university qualified and trained under the national-level SIYB training programs conducted by the ILO. Each had a minimum of five years experience delivering SIYB training. Therefore, any failure to find impacts should not be due to low quality trainers or inexperience with the materials. Those selected for training were offered a stipend of 1000 LKR and an additional bonus of 1500 LKR paid at the end if they attended all five days. The stipend was meant to cover transport and the opportunity cost of not working in the business on the training days.

Appendix Table 3 shows that assignment to these supplementary interventions is balanced compared to the control group and wage subsidy only groups in terms of baseline observable characteristics.

\footnotetext{
${ }^{19} \mathrm{http}: / /$ www.slbdc-lk.org/
} 
Appendix Table 3: Balance for Supplementary Treatments

\begin{tabular}{|c|c|c|c|c|c|c|c|}
\hline & $\begin{array}{l}\text { Control } \\
\text { Group }\end{array}$ & $\begin{array}{l}\text { Wage } \\
\text { Subsidy }\end{array}$ & $\begin{array}{c}\text { Wage Subsidy } \\
\text { \& Savings }\end{array}$ & $\begin{array}{c}\text { Wage Subsidy } \\
\text { \& Training }\end{array}$ & $\begin{array}{c}\text { Training } \\
\text { Only }\end{array}$ & $\begin{array}{c}\text { Savings } \\
\text { Only }\end{array}$ & $\begin{array}{l}\text { F-test } \\
\text { p-value }\end{array}$ \\
\hline \multicolumn{8}{|l|}{ Re-randomized Variables } \\
\hline Number of Paid Workers & 0.19 & 0.16 & 0.20 & 0.15 & 0.23 & 0.25 & 0.507 \\
\hline Education (Years) & 10.35 & 10.25 & 10.32 & 10.54 & 10.52 & 10.43 & 0.659 \\
\hline Raven Test Score & 3.34 & 3.34 & 3.32 & 3.12 & 3.28 & 3.35 & 0.687 \\
\hline Digitspan Recall Score & 6.42 & 6.36 & 6.35 & 6.39 & 6.27 & 6.21 & 0.681 \\
\hline Total Assets & 239893 & 250563 & 232635 & 203654 & 236665 & 258261 & 0.430 \\
\hline Total Assets $<1500$ LKR & 0.06 & 0.02 & 0.03 & 0.03 & 0.01 & 0.05 & 0.135 \\
\hline Total Assets>935000LKR & 0.05 & 0.06 & 0.04 & 0.03 & 0.04 & 0.05 & 0.743 \\
\hline Monthly Profits & 13862 & 14552 & 14010 & 12947 & 13282 & 13861 & 0.491 \\
\hline Profit Data Missing & 0.03 & 0.02 & 0.03 & 0.03 & 0.02 & 0.02 & 0.624 \\
\hline Monthly Profits<2000LKR & 0.06 & 0.03 & 0.03 & 0.04 & 0.03 & 0.04 & 0.896 \\
\hline Monthly Profits>30000LKR & 0.04 & 0.06 & 0.06 & 0.04 & 0.06 & 0.01 & 0.002 \\
\hline Business Practices Score & 8.27 & 8.76 & 8.24 & 8.59 & 9.24 & 8.35 & 0.440 \\
\hline From booster sample & 0.52 & 0.53 & 0.54 & 0.56 & 0.54 & 0.46 & 0.435 \\
\hline \multicolumn{8}{|l|}{ Stratification Variables } \\
\hline Retail Sector & 0.39 & 0.38 & 0.38 & 0.38 & 0.38 & 0.38 & 1.000 \\
\hline Colombo & 0.47 & 0.44 & 0.47 & 0.46 & 0.49 & 0.47 & 0.898 \\
\hline Kandy & 0.47 & 0.48 & 0.47 & 0.47 & 0.48 & 0.47 & 1.000 \\
\hline \multicolumn{8}{|l|}{ Additional Variables } \\
\hline Any paid worker at baseline & 0.12 & 0.10 & 0.13 & 0.09 & 0.15 & 0.12 & 0.385 \\
\hline Monthly Sales & 41175 & 52435 & 49142 & 41785 & 46768 & 34496 & 0.013 \\
\hline Owner's Age & 35.43 & 35.16 & 36.19 & 34.91 & 34.28 & 34.38 & 0.049 \\
\hline Business is Registered for Taxes & 0.31 & 0.32 & 0.32 & 0.31 & 0.31 & 0.40 & 0.478 \\
\hline Weekly hours worked & 57.94 & 59.31 & 60.77 & 60.41 & 57.20 & 59.78 & 0.496 \\
\hline Sample Size & 286 & 250 & 297 & 298 & 141 & 112 & \\
\hline
\end{tabular}


Appendix Table 3: Balance for Supplementary Treatments

\begin{tabular}{|c|c|c|c|c|c|c|c|}
\hline & $\begin{array}{l}\text { Control } \\
\text { Group }\end{array}$ & $\begin{array}{l}\text { Wage } \\
\text { Subsidy }\end{array}$ & $\begin{array}{c}\text { Wage Subsidy } \\
\text { \& Savings }\end{array}$ & $\begin{array}{c}\text { Wage Subsidy } \\
\text { \& Training }\end{array}$ & $\begin{array}{c}\text { Training } \\
\text { Only }\end{array}$ & $\begin{array}{c}\text { Savings } \\
\text { Only }\end{array}$ & $\begin{array}{l}\text { F-test } \\
\text { p-value }\end{array}$ \\
\hline \multicolumn{8}{|l|}{ Re-randomized Variables } \\
\hline Number of Paid Workers & 0.19 & 0.16 & 0.20 & 0.15 & 0.23 & 0.25 & 0.507 \\
\hline Education (Years) & 10.35 & 10.25 & 10.32 & 10.54 & 10.52 & 10.43 & 0.659 \\
\hline Raven Test Score & 3.34 & 3.34 & 3.32 & 3.12 & 3.28 & 3.35 & 0.687 \\
\hline Digitspan Recall Score & 6.42 & 6.36 & 6.35 & 6.39 & 6.27 & 6.21 & 0.681 \\
\hline Total Assets & 239893 & 250563 & 232635 & 203654 & 236665 & 258261 & 0.430 \\
\hline Total Assets $<1500$ LKR & 0.06 & 0.02 & 0.03 & 0.03 & 0.01 & 0.05 & 0.135 \\
\hline Total Assets>935000LKR & 0.05 & 0.06 & 0.04 & 0.03 & 0.04 & 0.05 & 0.743 \\
\hline Monthly Profits & 13862 & 14552 & 14010 & 12947 & 13282 & 13861 & 0.491 \\
\hline Profit Data Missing & 0.03 & 0.02 & 0.03 & 0.03 & 0.02 & 0.02 & 0.624 \\
\hline Monthly Profits<2000LKR & 0.06 & 0.03 & 0.03 & 0.04 & 0.03 & 0.04 & 0.896 \\
\hline Monthly Profits>30000LKR & 0.04 & 0.06 & 0.06 & 0.04 & 0.06 & 0.01 & 0.002 \\
\hline Business Practices Score & 8.27 & 8.76 & 8.24 & 8.59 & 9.24 & 8.35 & 0.440 \\
\hline From booster sample & 0.52 & 0.53 & 0.54 & 0.56 & 0.54 & 0.46 & 0.435 \\
\hline \multicolumn{8}{|l|}{ Stratification Variables } \\
\hline Retail Sector & 0.39 & 0.38 & 0.38 & 0.38 & 0.38 & 0.38 & 1.000 \\
\hline Colombo & 0.47 & 0.44 & 0.47 & 0.46 & 0.49 & 0.47 & 0.898 \\
\hline Kandy & 0.47 & 0.48 & 0.47 & 0.47 & 0.48 & 0.47 & 1.000 \\
\hline \multicolumn{8}{|l|}{ Additional Variables } \\
\hline Any paid worker at baseline & 0.12 & 0.10 & 0.13 & 0.09 & 0.15 & 0.12 & 0.385 \\
\hline Monthly Sales & 41175 & 52435 & 49142 & 41785 & 46768 & 34496 & 0.013 \\
\hline Owner's Age & 35.43 & 35.16 & 36.19 & 34.91 & 34.28 & 34.38 & 0.049 \\
\hline Business is Registered for Taxes & 0.31 & 0.32 & 0.32 & 0.31 & 0.31 & 0.40 & 0.478 \\
\hline Weekly hours worked & 57.94 & 59.31 & 60.77 & 60.41 & 57.20 & 59.78 & 0.496 \\
\hline Sample Size & 286 & 250 & 297 & 298 & 141 & 112 & \\
\hline
\end{tabular}




\section{Appendix 4: Measurement of Key Variables}

Our key outcomes are measured as follows:

Survival: we examine survival in terms of whether the individual is self-employed at the time of the survey. This includes those who have shut down their business and started a new one. It is directly measured by asking whether they are engaged in self-employment on the survey, and through direct observation and asking family and neighbors for those firms which attrit. Where the original respondent cannot be located, beginning in round 7 (April 2011) we ask family members or neighbors whether the individual still operates the business they previously operated. When the alternative respondent says no, we ask what them what the initial respondent is presently doing. In our baseline specifications, we use responses from the first but not the second to define the survival variable. We do this because we believe the information on whether the original business is still operating is likely to be more reliable. An alternative approach would be to use both responses to define whether the individual still operates any business. The results from this approach are qualitatively similar, though the treatment effect in the second year after treatment is slightly larger in magnitude. Regressions using this alternative definition are available from the authors on request.

Number of Paid Workers: this is the number of permanent workers plus the number of casual and daily workers reported on the survey. It is truncated at 5 workers (the $99^{\text {th }}$ percentile) to reduce the influence of outliers, and coded as 0 for firms that do not survive.

Any paid worker: defined as having at least one paid worker.

Added a worker between survey rounds: defined as the number of paid workers in round $t$ exceeding that in round $t-1$. It therefore measures net, rather than gross, worker flows.

Subtracted a worker between survey rounds: defined as the number of paid workers in round $t$ being less than in round $t-1$.

Own hours reported in the business: the number of hours worked in the business in the last week, truncated at the $99^{\text {th }}$ percentile, and coded as 0 for individuals not self-employed.

Number of unpaid workers in the business: Number of unpaid workers reported by the firm owner. 
Firm profits: these are monthly, and were asked directly of the owner as "the total income of the business during each of the last month after paying all expenses including wages of employees, but not including any income you paid yourself". This follows the wording and recommendation of De Mel et al. (2009). ${ }^{20}$ We consider several transforms of profits to deal with outliers and firm closure. This includes unconditional profits (which put zeroes in for closed firms) truncated at the $99^{\text {th }}$ percentile, the inverse hyperbolic sine of profits, truncated profits conditional on the business operating, and log profits conditional on operation. Nominal values were deflated to real values using the Consumer Price Index for Colombo, gathered by the Sri Lankan Department of Census and Statistics.

Firm sales: these are firm sales in the past month, deflated into real terms using the CPI. As with profits, we consider several transforms of the raw data to account for outliers and firm closure, with the variables defined analogously to profits.

\section{Business Practices score:}

The total score - the composite business practice score -- ranges from a minimum of -1 to a maximum of 29. The total is the sum of the following component scores: the marketing score, the stock score, the records score, and the financial planning score.

The marketing score ranges from 0 to 7 , and it is calculated by adding one point for each of the following that the business has done in the last 3 months:

- Visited at least one of its competitor's businesses to see what prices its competitors are charging

- Visited at least one of its competitor's businesses to see what products its competitors have available for sale

- Asked existing customers whether there are any other products the customers would like the business to sell or produce

- Talked with at least one former customer to find out why former customers have stopped buying from this business

- Asked a supplier about which products are selling well in this business' industry

- Attracted customers with a special offer

- Advertised in any form (last 6 months)

The stock score ranges from -1 to 2, and it is calculated by subtracting one point

- If the business runs out of stock once a month or more

And adding one point for each of the following that the business has done in the last 3 months

\footnotetext{
${ }^{20}$ De Mel, Suresh, David McKenzie and Christopher Woodruff (2009) "Measuring Microenterprise Profits: Must We Ask How the Sausage Is Made?”,Journal of Development Economics, 88(1): 19-31.
} 
- Attempted to negotiate with a supplier for a lower price on raw material

- Compared the prices or quality offered by alternate suppliers or sources of raw materials to the business' current suppliers or sources of raw material

The records score ranges from 0 to 8 , and it is calculated by adding one point for each of the following that the business does

- Keeps written business records

- Records every purchase and sale made by the business

- Able to use records to see how much cash the business has on hand at any point in time

- Uses records regularly to know whether sales of a particular product are increasing or decreasing from one month to another

- Works out the cost to the business of each main product it sells

- Knows which goods you make the most profit per item selling

- Has a written budget, which states how much is owed each month for rent, electricity, equipment maintenance, transport, advertising, and other indirect costs to business

- Has records documenting that there exists enough money each month after paying business expenses to repay a loan in the hypothetical situation that this business wants a bank loan

The financial planning score ranges from $0-12$, and it is calculated by adding up to three points for each of the following two questions

- How frequently do you review the financial performance of your business and analyze where there are areas for improvement

- How frequently do you compare performance to your target

○ Zero points for "Never"

- One point for "Once a year or less"

- Two points for "Two or three times a year"

○ Three points for "Monthly or more often"

And adding one point for each of the following that the business has

- A target set for sales over the next year

- A budget of the likely costs your business will have to face over the next year

- An annual profit and loss statement

- An annual statement of cash flow

- An annual balance sheet

- An annual income/expenditure sheet

Wage worker and SME surveys

We also make use of data from surveys of wage workers and larger firms. The wage worker survey was conducted in all urban areas in Sri Lanka at annual intervals from 2008-2011. The 
initial sample was drawn from a listing of households in randomly selected Grama Niladhari divisions. The SME survey of larger firm owners selected surveyed firms with between 5 and 250 workers (including the owner). This sample was drawn from a listing of visible enterprises conducted for other purposes by the Sri Lanka office of AC Nielsen. We surveyed owners first in April 2008, and resurveyed in April 2009 and April 2010. The questions from the wage worker and SME surveys that we used in the analysis for this paper are described in the text.

\section{Appendix 5: Round by Round Survey Attrition Rate}

Appendix Figure 5 shows the attrition rate by round, in terms of whether we have information on whether the business is still open/the owner is self-employed, and in terms of whether we can measure whether the enterprise has paid workers. Starting in round 7 we added a module which collected information from relatives, friends, and neighboring businesses if the business was not able to be interviewed, resulting in a reduction in attrition at that time. The attrition rate averages 5.6 percent for data on whether the business is operating, and 9 percent for data on whether the business has paid workers. Attrition rates are balanced for treatment and control in most waves, and in the last round we have data on employment for all but 8 percent of firms. 


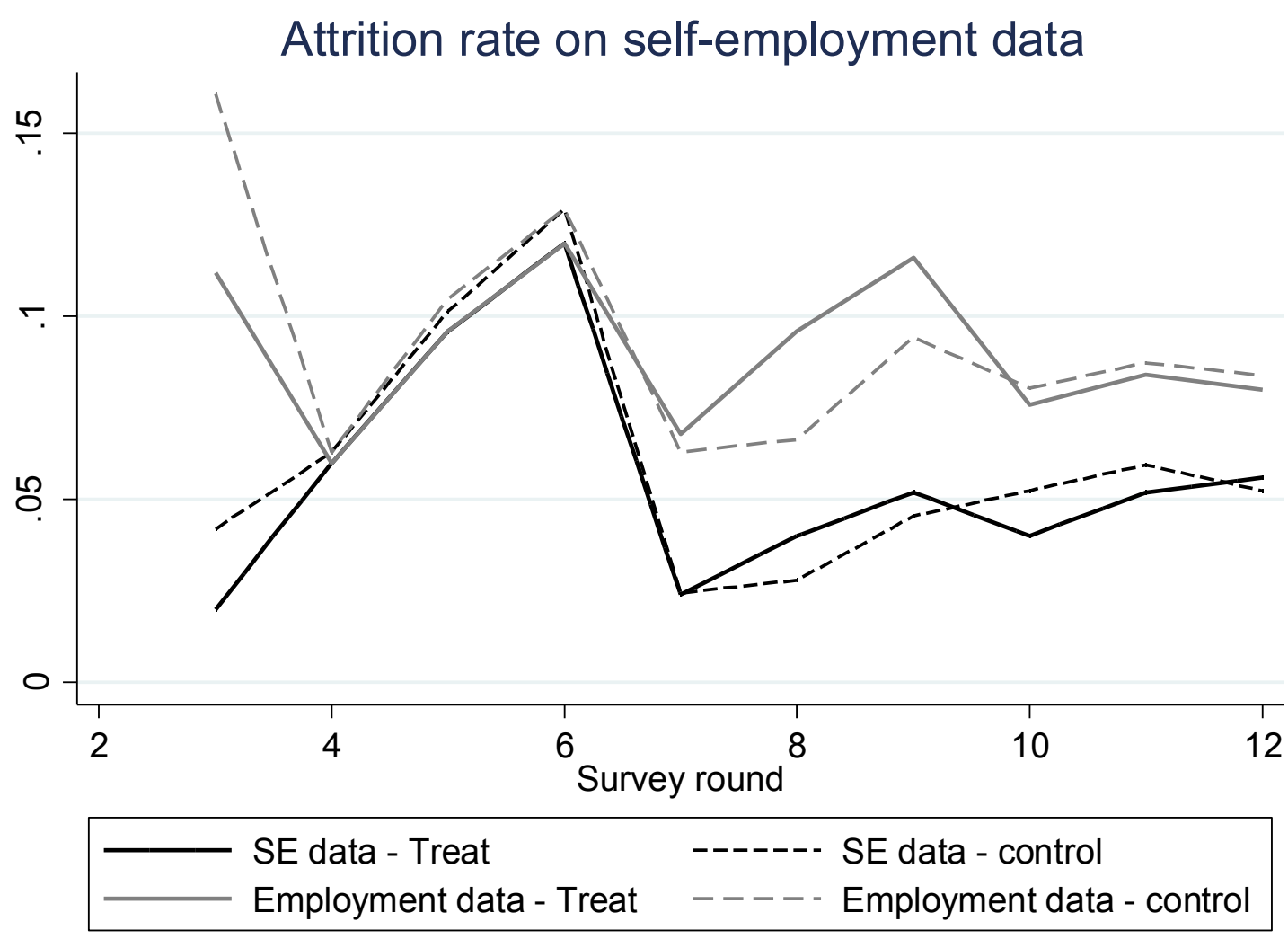

\section{Appendix 6: Does treatment change which firms have workers?}

Appendix Table 6.1 compares the baseline characteristics of the subsample of treatment and control firms which have a paid employee in round 4 (during the intervention), and in round 12 (the last survey round). This comparison allows us to see the extent to which the wage subsidy changes which firms have paid workers. We see little selectivity in terms of owner's education, raven, and digit span scores. During the intervention, the firms hiring workers who would not have done so if they were in the control group appear to be smaller (lower profits, lower total assets) and outside of Colombo. However, by the time of the last survey, the profit difference has disappeared, and only the geographic difference remains. 
Appendix Table 6.1: Does Treatment Change Which Firms Have Workers?

\begin{tabular}{|c|c|c|c|c|c|c|}
\hline & \multicolumn{3}{|c|}{ Have a Worker in Round 4} & \multicolumn{3}{|c|}{ Have a Worker in Round 12} \\
\hline & Control & Treatment & $p$-value & Control & Treatment & $p$-value \\
\hline Number of Paid Workers & 0.43 & 0.27 & 0.157 & 0.47 & 0.30 & 0.213 \\
\hline Education (Years) & 10.17 & 10.33 & 0.682 & 10.60 & 10.63 & 0.943 \\
\hline Raven Test Score & 3.19 & 3.23 & 0.891 & 3.08 & 3.08 & 0.985 \\
\hline Digitspan Recall Score & 6.51 & 6.55 & 0.858 & 6.56 & 6.50 & 0.816 \\
\hline Total Assets & 332819 & 280911 & 0.483 & 320187 & 349938 & 0.752 \\
\hline Total Assets<1500LKR & 0.01 & 0.02 & 0.750 & 0.03 & 0.02 & 0.633 \\
\hline Total Assets>935000LKR & 0.09 & 0.06 & 0.584 & 0.10 & 0.13 & 0.609 \\
\hline Monthly Profits & 20500 & 15473 & 0.029 & 17927 & 17759 & 0.953 \\
\hline Profit Data Missing & 0.01 & 0.02 & 0.750 & 0.03 & 0.02 & 0.633 \\
\hline Monthly Profits<2000LKR & 0.03 & 0.01 & 0.394 & 0.07 & 0.02 & 0.129 \\
\hline Monthly Profits $>30000$ LKR & 0.09 & 0.07 & 0.778 & 0.06 & 0.08 & 0.600 \\
\hline Business Practices Score & 8.79 & 10.19 & 0.146 & 9.64 & 10.30 & 0.541 \\
\hline From booster sample & 0.53 & 0.58 & 0.523 & 0.49 & 0.53 & 0.602 \\
\hline Retail Sector & 0.31 & 0.34 & 0.762 & 0.36 & 0.28 & 0.324 \\
\hline Colombo & 0.50 & 0.33 & 0.024 & 0.47 & 0.30 & 0.037 \\
\hline Kandy & 0.46 & 0.56 & 0.203 & 0.44 & 0.61 & 0.055 \\
\hline Any paid worker at baseline & 0.29 & 0.18 & 0.105 & 0.29 & 0.17 & 0.102 \\
\hline Monthly Sales & 57161 & 67089 & 0.414 & 49053 & 61765 & 0.276 \\
\hline Owner's Age & 36.93 & 35.01 & 0.046 & 36.65 & 35.00 & 0.122 \\
\hline Business is Registered for Tax & 0.37 & 0.26 & 0.139 & 0.35 & 0.27 & 0.307 \\
\hline Weekly hours worked & 59.20 & 60.07 & 0.741 & 56.83 & 57.13 & 0.916 \\
\hline
\end{tabular}

Notes: characteristics are baseline characteristics. P-value compares whether characteristics of firms having a paid worker in round 4 (during the intervention), and in round 12 (last survey) are similar for the treatment and control groups using a t-test of equality of means.

Appendix Figure 6 explores further how the baseline profitability of those hiring workers during the intervention period compares in the treatment and control groups, and to those who already had workers and those who never hired a worker amongst the treatment group. We see the treatment brings into hiring workers firms with lower profits than those hiring workers in the control group, and than those who already had workers in the treatment group. Those hiring workers in the treatment group have a similar baseline profits distribution to those who never hire a worker during the intervention period.

Appendix Figure 6: Treated Firms Hiring Workers During Intervention Were Lower Profit Firms 

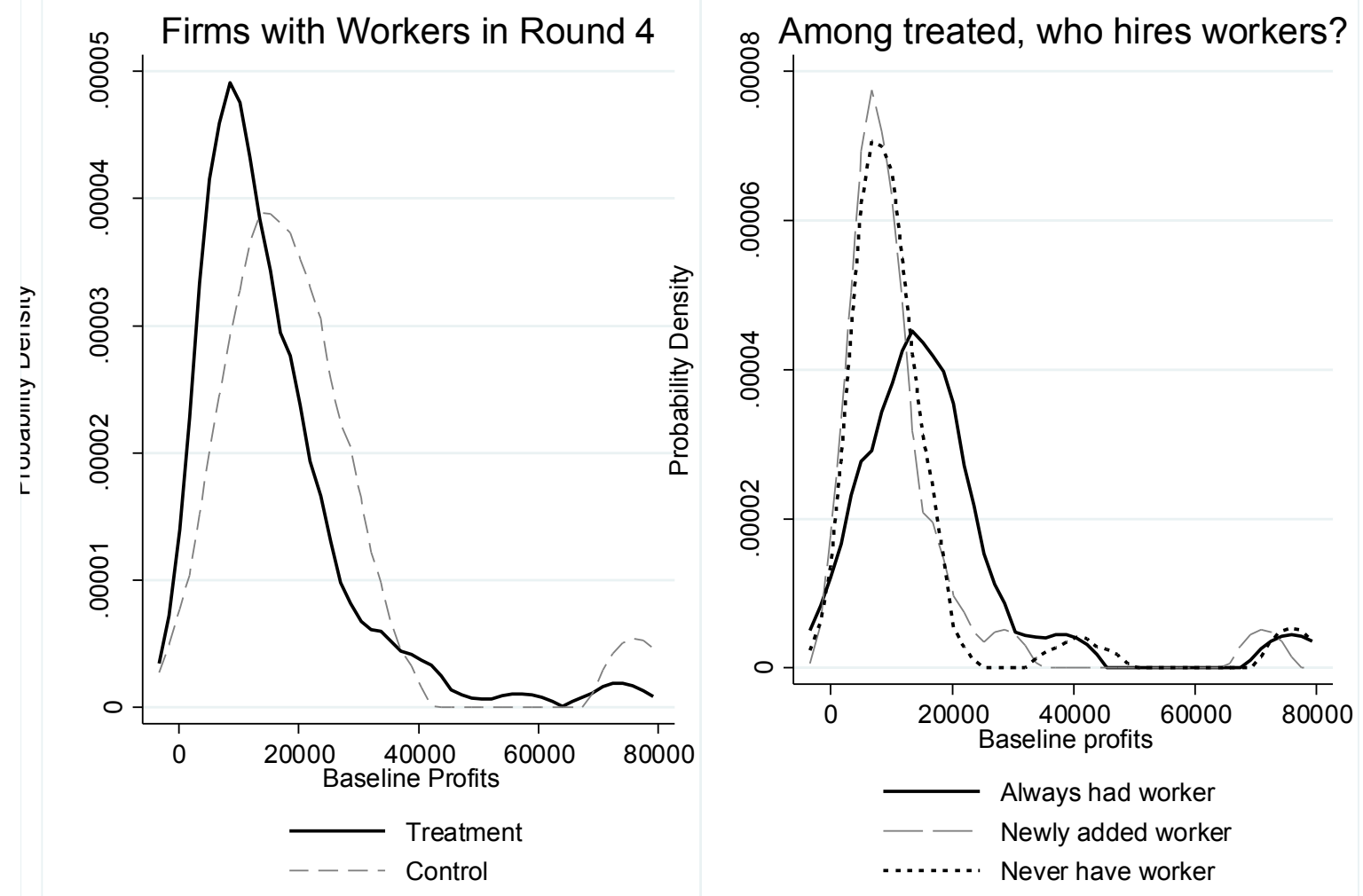

Appendix Table 6.2 then looks within the treatment group to see how the baseline characteristics of those who hire a worker during the intervention period and then reduce employment again compare to those who hire a worker and maintain this new employment level for at least a year after. The same is done for the control group, although only 8 control firms hire a worker and then don't reduce employment again afterwards. We see few significant differences, suggesting that those who keep the worker look quite similar on observable baseline characteristics to those which do not. The one difference is again in terms of geography: although firms in Colombo were less likely to respond to the wage subsidy, those that did hire workers were more likely to keep them on afterwards than those in the other cities. 


\begin{tabular}{|c|c|c|c|c|c|c|}
\hline & \multicolumn{3}{|c|}{ Wage Subsidy Treatment Group } & \multicolumn{3}{|c|}{ Control Group } \\
\hline & $\begin{array}{c}\text { Hire and } \\
\text { Let Go }\end{array}$ & $\begin{array}{c}\text { Hire and } \\
\text { Keep }\end{array}$ & p-value & $\begin{array}{c}\text { Hire and } \\
\text { Let Go }\end{array}$ & $\begin{array}{c}\text { Hire and } \\
\text { Keep }\end{array}$ & p-value \\
\hline Education (Years) & 10.38 & 9.87 & 0.434 & 10.00 & 10.38 & 0.683 \\
\hline Raven Test Score & 3.11 & 2.91 & 0.694 & 2.91 & 3.88 & 0.202 \\
\hline Total Assets $<1500$ LKR & 0.02 & 0.09 & 0.110 & 0.00 & 0.00 & . \\
\hline Total Assets>935000LKR & 0.06 & 0.04 & 0.740 & 0.07 & 0.13 & 0.574 \\
\hline Monthly Profits & 15167 & 15036 & 0.969 & 17197 & 19921 & 0.618 \\
\hline Profit Data Missing & 0.02 & 0.04 & 0.450 & 0.00 & 0.00 & . \\
\hline Retail Sector & 0.36 & 0.17 & 0.101 & 0.27 & 0.63 & 0.046 \\
\hline Colombo & 0.31 & 0.57 & 0.032 & 0.49 & 0.63 & 0.487 \\
\hline Kandy & 0.58 & 0.30 & 0.024 & 0.44 & 0.38 & 0.721 \\
\hline Any paid worker at baseline & 0.16 & 0.13 & 0.769 & 0.22 & 0.25 & 0.866 \\
\hline Monthly Sales & 56787 & 57263 & 0.981 & 49618 & 61307 & 0.552 \\
\hline Owner's Age & 35.41 & 34.30 & 0.509 & 35.60 & 38.38 & 0.250 \\
\hline Business is Registered for Taxes & 0.31 & 0.22 & 0.393 & 0.29 & 0.25 & 0.826 \\
\hline Weekly hours worked & 59.94 & 58.74 & 0.770 & 57.51 & 62.50 & 0.482 \\
\hline Sample Size & 64 & 23 & & 45 & 8 & \\
\hline
\end{tabular}

Notes: Hire and Let go indicates the firm hired a worker during the intervention period (rounds 4 and 5), but then lowered the number of employees compared to the previous round in one of round 4,5 , or 6 . Hire and Keep indicates they hired a worker and did not then reduce their number of employees in the first year after the intervention.

\section{Appendix 7: Heterogeneity in Survival Impact}

We estimate equation (5), adding treatment interactions, the baseline value of the interacting variable, and the interactions between this interacting variable and survey round. We do this for the outcome of business survival, and report the results in Appendix Table 7. The first column shows no heterogeneity in the treatment effect on survival with respect to baseline business practices. The second column shows that firms with initially low capital have a higher treatment effect for survival. The interactions of treatment with above median baseline capital are significant at the 10 percent levels in years 2, and years 3 and 4 . The magnitude of the coefficients is almost enough to entirely offset the treatment effect, suggesting the treatment effect only occurs for low capital firms. Appendix Figure 7 shows this graphically: the control group sample with low baseline assets dies at a faster rate over time than the control group sample with high baseline assets, whereas the death rates for the low asset treated are similar to 
those of the high asset treated and the high asset control. Nevertheless, a joint test that all interactions are zero cannot reject the null hypothesis. Column 3 likewise shows higher point estimates for the treatment effect on survival for firms with initially low profitability, with negative, but not statistically significant, interaction effects with having above median profit.

\begin{tabular}{lccc} 
Appendix Table 7: Heterogeneity in Survival & & \\
\hline Before Subsidy & -0.011 & 0.017 & -0.023 \\
& $(0.046)$ & $(0.038)$ & $(0.034)$ \\
During Subsidy & 0.006 & -0.012 & -0.012 \\
& $(0.031)$ & $(0.030)$ & $(0.028)$ \\
Year 1 After & 0.052 & $0.075^{* *}$ & $0.069^{* *}$ \\
& $(0.038)$ & $(0.032)$ & $(0.030)$ \\
Year 2 After & $0.083^{*}$ & $0.114^{* * *}$ & $0.097^{* *}$ \\
& $(0.046)$ & $(0.038)$ & $(0.038)$ \\
Years 3-4 After & 0.065 & $0.104^{* * *}$ & 0.059 \\
& $(0.049)$ & $(0.040)$ & $(0.040)$ \\
Interaction with & & & \\
& $b u s i n e s s$ & $a b o v e$ & $a b o v e$ \\
Before Subsidy*Interaction & practices & median capital & median profit \\
During Subsidy*Interaction & 0.001 & -0.051 & 0.033 \\
& $(0.004)$ & $(0.046)$ & $(0.048)$ \\
Year 1 After*Interaction & -0.002 & 0.005 & 0.006 \\
& $(0.003)$ & $(0.035)$ & $(0.037)$ \\
Year 2 After*Interaction & 0.000 & -0.042 & -0.026 \\
Years 3-4 After*Interaction & $(0.004)$ & $(0.041)$ & $(0.043)$ \\
& -0.001 & $-0.085^{*}$ & -0.045 \\
Sample Size & $(0.004)$ & $(0.049)$ & $(0.051)$ \\
P-value & -0.001 & $-0.097^{*}$ & -0.000 \\
\hline Notes: robust standard & $(0.005)$ & $(0.052)$ & $(0.054)$ \\
& & & 5005 \\
& 5005 & 5005 & 0.785 \\
\hline & 0.962 & 0.368 & \\
& & &
\end{tabular}

Notes: robust standard errors in parentheses, clustered at the firm level.

All regressions control for randomization strata, variables used for re-randomization, survey round, baseline value of interacting variable and interaction between this interacting variable and survey round.

$*, * *, * * *$ indicate significance at the 10,5 , and 1 percent levels respectively. 
Appendix Figure 7: Heterogeneous Survival Effects by Baseline Capital

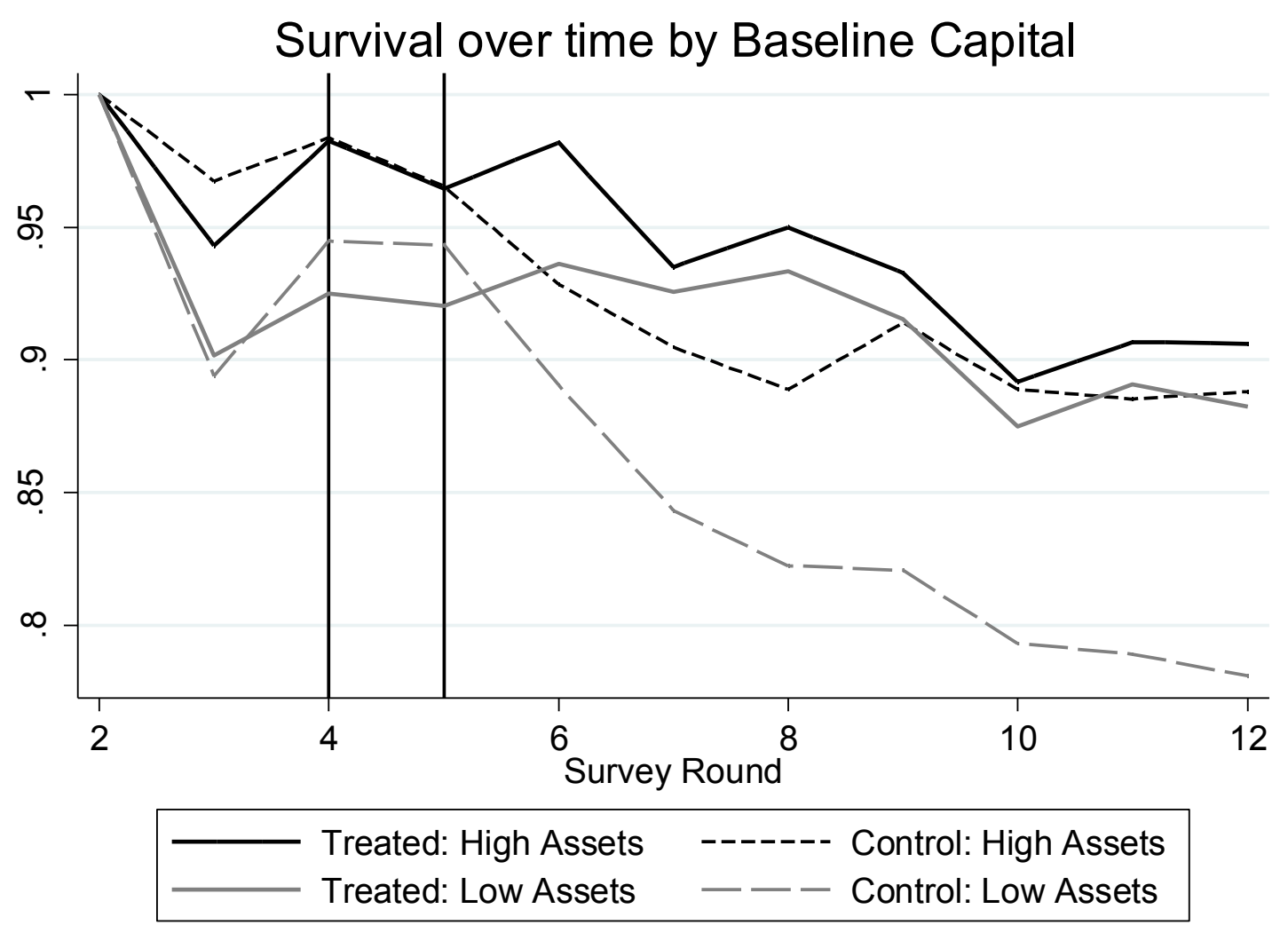

Note: High Asset and Low Asset are defined as having above and below the baseline median capital stock level respectively. 